\title{
Modulation of depression-related behaviors by adiponectin AdipoR1 receptors in 5-HT neurons
}

\author{
Chen $\mathrm{Li}^{1,2} \cdot$ Fantao Meng ${ }^{1} \cdot$ Jacob C. Garza ${ }^{2,3} \cdot$ Jing Liu $^{1} \cdot$ Yun Lei ${ }^{2} \cdot$ Sergei A. Kirov ${ }^{2} \cdot$ Ming Guo $^{1,2} \cdot$ Xin-Yun Lu $^{2}$
}

Received: 8 October 2019 / Revised: 20 December 2019 / Accepted: 10 January 2020 / Published online: 24 January 2020

(c) The Author(s) 2020. This article is published with open access

\begin{abstract}
The adipocyte-derived hormone adiponectin has a broad spectrum of functions beyond metabolic control. We previously reported that adiponectin acts in the brain to regulate depression-related behaviors. However, its underlying neural substrates have not been identified. Here we show that adiponectin receptor 1 (AdipoR1) is expressed in the dorsal raphe nucleus (DRN) and colocalized with tryptophan hydroxylase 2 (TPH2), a marker of serotonin (5-HT) neurons. Selective deletion of AdipoR1 in 5-HT neurons induced anhedonia in male mice, as indicated by reduced female urine sniffing time and saccharin preference, and behavioral despair in female mice and enhanced stress-induced decrease in sucrose preference in both sexes. The expression levels of TPH2 were downregulated with a concurrent reduction of 5-HT-immunoreactivity in the DRN and its two major projection regions, the hippocampus and medial prefrontal cortex (mPFC), in male but not female mice lacking AdipoR1 in 5-HT neurons. In addition, serotonin transporter (SERT) expression was upregulated in both DRN projection fields of male mice but only in the mPFC of female mice. These changes presumably lead to decreased 5-HT synthesis and/or increased 5-HT reuptake, thereby reducing 5-HT transmission. The augmented behavioral responses to the selective serotonin reuptake inhibitor fluoxetine but not desipramine, a selective norepinephrine reuptake inhibitor, observed in conditional knockout male mice supports deficient 5-HT transmission underlying depression-related phenotypes. Our results indicate that adiponectin acts on 5-HT neurons through AdipoR1 receptors to regulate depression-related behaviors in a sex-dependent manner.
\end{abstract}

\section{Introduction}

Adiponectin is a hormone secreted almost exclusively by adipocytes [1, 2]. In plasma, adiponectin exists as either a full-length protein or a globular fragment generated by proteolytic cleavage of the full-length protein [3, 4]. Full-length adiponectin is the predominant circulating form and can be found as a trimer, hexamer, or high-molecular

Chen $\mathrm{Li}$

CHLI@augusta.edu

Xin-Yun Lu

xylu@augusta.edu

1 Institute for Metabolic \& Neuropsychiatric Disorders, Binzhou Medical University Hospital, Binzhou, Shandong, China

2 Department of Neuroscience \& Regenerative Medicine, Medical College of Georgia at Augusta University, Augusta, GA, USA

3 Present address: Center for Genomic Medicine and Department of Psychiatry, Massachusetts General Hospital, Harvard Medical School, Boston, MA, USA weight oligomer [5, 6]. Multiple lines of evidence indicate that adiponectin enters the brain from circulation. Trimeric and hexameric forms of adiponectin can be found in the cerebrospinal fluid (CSF) of humans and animals [7-10] and intravenous injection of adiponectin increases CSF adiponectin levels $[10,11]$. Furthermore, adiponectin can be detected in the CSF of homozygous adiponectin-deficient mice after intravenous injection of full-length adiponectin, indicating that adiponectin can cross the blood-brain barrier $[9,12]$.

Low plasma adiponectin levels are commonly associated with insulin resistance in obesity and type 2 diabetes $[13,14]$, which can increase the risk of depression and anxiety $[15,16]$. Some clinical studies indicate a negative correlation between depression severity and circulating adiponectin [17-20]. The association between hypoadiponectinemia and depression remains significant even after controlling for metabolic status or excluding obesity and diabetes [17-19], suggesting that low adiponectin levels can be an independent risk factor for depression. Our preclinical studies have found that adiponectin haploinsufficiency or immunoneutralization of adiponectin in the brain increases 
the susceptibility to depression-related behaviors [21]. By contrast, intracerebroventricular administration of exogenous adiponectin produces antidepressant-like behavioral effects in normal and diet-induced obese mice [21]. These results suggest that adiponectin regulates depression-related behaviors through a central mechanism.

Adiponectin exerts its effects via two distinct receptors, AdipoR1 and AdipoR2. Both receptors contain seven transmembrane domains but, unlike G-protein coupled receptors, have an intracellular amino terminus and an extracellular carboxyl terminus [22]. AdipoR1 and AdipoR2 have distinct distribution patterns and bind to various forms of adiponectin with different affinity [22]. While AdipoR1 is widely expressed in the brain, AdipoR2 is restricted to only a few brain regions $[9,21]$. We have shown that AdipoR1 and AdipoR2 signaling in the hippocampus and ventral tegmental area are involved in the regulation of anxiety-related behavior and fear memories in a mouse model of post-traumatic disorder [23, 24]. However, the specific roles of AdipoR1 and AdipoR2 in depression-related behaviors and the underlying neural substrates remain to be elucidated.

The serotonin (5-HT) system has been implicated in the pathophysiology and treatment of depression [25, 26]. A central role of 5-HT in depression is supported by therapeutic actions of augmenting 5-HT function, more specifically, increasing 5-HT levels in the synaptic cleft [27, 28]. Most of antidepressants, especially selective serotonin reuptake inhibitors (SSRIs), increase synaptic 5-HT activity [29]. On the other hand, several lines of evidence suggest the presence of 5-HT deficiency in depression [30]. Acute depletion of tryptophan, an essential amino acid precursor of 5-HT, induces depressive relapse in remitted patients with major depressive disorder by lowering serotonin synthesis [31, 32]. Treatment with the vesicular monoamine transporter inhibitor reserpine depletes monoamines, resulting in depression [33], which is often cited as the earliest evidence in support of the monoamine hypothesis of depression. Moreover, low CSF concentrations of 5-hydroxyindoleacetic acid (5-HIAA), the metabolite of 5-HT, were found in depressed patients [34], and mutations of genes encoding key components of the 5-HT system have been associated with affective disorders and stress sensitivity [35-37]. However, the effects of brain 5-HT deficiency on stress susceptibility and the development of depression-related behaviors are not well understood.

In this study, we investigated the anatomical basis of functional interactions between adiponectin signaling and the 5-HT system. We generated AdipoR1 conditional knockout mice and determined the impact of loss of AdipoR1 specifically in 5-HT neurons on depression- and anxiety-related behaviors, expression of key components of the 5-HT system and antidepressant responses in both male and female mice.

\section{Materials and Methods}

\section{Animals}

Wild-type (WT) C57BL/6J mice (Stock No. 000664) were purchased from Jackson Laboratory (Bar Harbor, ME, USA). Ai14 mice that express robust tdTomato fluorescence following Cre-mediated recombination (Stock No. 007908) and mice hemizygous for the ePet-Cre transgene (Stock No. 012712) that were backcrossed to a C57BL/6J background were obtained from Jackson Laboratory. To confirm the specificity of ePet-Cre-mediated recombination in serotonin (5-HT) synthesis neurons, ePet-Cre mice were crossed with the Ai14 tdTomato reporter line to obtain ePet-Cre, Ai14 mice with tdTomato fluorescence in Cre-expressing cells, which was used to determine the colocalization of tdTomato with 5-HT neuron-specific markers. To generate conditional knockout mice lacking AdipoR1 in 5-HT neurons, Adi$\operatorname{poR} 1^{\text {flox/flox }}$ (AdipoR $1^{\mathrm{f} / \mathrm{f}}$ ) mice, in which exon 2 is floxed [23], were crossed with ePet-Cre mice. The AdipoR $1^{\text {flox/+}}$, ePet-Cre offspring were backcrossed with AdipoR $1^{\mathrm{f} / \mathrm{R}}$ mice to generate AdipoR $1^{\mathrm{f} / \mathrm{f}}$, ePet-Cre (AdipoR $1^{\mathrm{f} / \mathrm{f} \text {;ePt-Cre }}$ ), and AdipoR $1^{\mathrm{f} / \mathrm{f}}$ littermate controls. The PCR primers used for genotyping were as follows: ePet-Cre, forward-5'-GCG GTCTG GCAGTAAAAACTATC-3', reverse-5'-GTGAAACAGCA TTGCTGTCACTT- ${ }^{\prime}$, and AdipoR1 WT and flox, forward5'-CCCTGGGGATAGTTCTGGAT-3', reverse-5'-TTACT CACTGGGCCCTGCTTG-3'. All mice were housed in groups of five per cage under a 12-h light/dark cycle (lights on at 7:00 a.m.) with ad libitum access to water and standard food pellets. Both male and female mice at an age between 8 and 15 weeks were used and all animal procedures were approved by the Institutional Animal Care and Use Committee of Binzhou Medical University Hospital and Augusta University.

\section{Drugs}

Fluoxetine and desipramine (Sigma-Aldrich, ST. Louis, MO, USA) were dissolved in saline $(0.9 \% \mathrm{NaCl} \mathrm{w} / \mathrm{v})$ to a final concentration of $1 \mathrm{mg} \mathrm{mL}^{-1}$ for intraperitoneally (i.p.) injection with a dose of 5 or $10 \mathrm{mg} \mathrm{kg}^{-1}$.

\section{Quantitative real-time PCR analysis}

Mice were decapitated and the brains were removed rapidly. The medial prefrontal cortex (mPFC) and hippocampus were immediately dissected on ice. The DRN was dissected from five to six 100- $\mu$ m-thick coronal midbrain slices (from 
-4.36 to $-4.96 \mathrm{~mm}$ from bregma) on ice according to the mouse brain atlas [38]. Total RNA was extracted from each tissue sample to generate cDNA using a protocol reported elsewhere [39, 40]. First, total RNA was treated with $4 \times$ gDNA wiper mix at $42{ }^{\circ} \mathrm{C}$ for 2 min to remove genomic DNA contamination, then reversely transcribed into cDNAs with $5 \times$ HiScript II QRT SuperMix that was added to the reaction mixture and incubated at $25^{\circ} \mathrm{C}$ for $10 \mathrm{~min}$ followed by $50{ }^{\circ} \mathrm{C}$ for $30 \mathrm{~min}$ and $85^{\circ} \mathrm{C}$ for $5 \mathrm{~min}$. The resulting cDNA was used for real-time PCR detection using the StepOnePlus real-time PCR system (Applied Biosystems, Waltham, MA, USA). The condition for PCR was $95^{\circ} \mathrm{C}$ for $5 \mathrm{~min}$, followed by 40 cycles of $95^{\circ} \mathrm{C}$ for $10 \mathrm{~s}$ and $60^{\circ} \mathrm{C}$ for $30 \mathrm{~s}$. The primer sequences used to amplify each desired product were as follows: mouse AdipoR1 exon 2 [23], forward-5'-CCCGTATCCACCAGACACCGG-3', reverse$5^{\prime}$-GGCAATGGGGCTCCTTCTGG-3'; mouse $\beta$-tubulin [39], forward-5'-AGCAACATGAATGACCTGGTG-3', reverse-5'-GCTTTCCCTAACCTGCTTGG-3'. The housekeeping gene $\beta$-tubulin was used as a reference gene for normalization of gene expression. The $2^{-\Delta \Delta C T}$ method, i.e., delta-delta-ct analysis, was used as a relative quantification $[40,41]$.

\section{In situ hybridization}

Radioactive in situ hybridization for detecting AdipoR1 and AdipoR2 gene expression patterns were performed as previously described [21, 24]. Briefly, the brain tissue (fresh frozen) was cut at a thickness of $20 \mu \mathrm{m}$, mounted onto polylysine coated slides and sequentially fixed in $4 \%$ paraformaldehyde for $1 \mathrm{~h}$ followed by a rinse in $2 \times$ saline sodium citrate (SSC) buffer $(300 \mathrm{mM} \mathrm{NaCl}, 30 \mathrm{mM}$ Na citrate, $\mathrm{pH}$ 7.2), acetylated in $0.1 \mathrm{M}$ triethanolamine $(\mathrm{pH}$ 8.0) with $0.25 \%$ ( vol $/ \mathrm{vol}$ ) acetic anhydride for $10 \mathrm{~min}$ and dehydrated through a graded series of alcohol (50-100\%). AdipoR1 and AdipoR2 cDNA fragments were amplified by RT-PCR using the primers as follows: AdipoR1 (721 bp), forward: 5'-CCGCTCGAGGATCGGGCGCCCCTC-3' and reverse: 5'-CGGGATCCCGAAGACCACCTTC-3'; and AdipoR2 (912 bp), forward: 5'-CCGCTCGAGTGTAACATGGGC CTCG-3' and reverse: 5'-CGGGATCCCCAAAAGTGT GC-3'. The cDNA fragments were cloned into pBluescript II SK + vector (Stratagene, San Diego, CA, USA). To generate radiolabeled cRNA probes, the plasmids were linearized and labeled with $S^{35}$-UTP and $S^{35}$-CTP (PerkinElmer, Waltham, MA, USA) using the standard transcription system. The brain tissue sections were incubated with $70 \mu \mathrm{l}$ of radioactive $\mathrm{S}^{35}$-labeled AdipoR1 or AdipoR2 cRNA probes at $55^{\circ} \mathrm{C}$ overnight, rinsed in $2 \times \mathrm{SSC}$ and incubated in RNase A buffer $(200 \mathrm{mg} / \mathrm{ml})$ for $1 \mathrm{~h}$ at $37^{\circ} \mathrm{C}$ followed by a series of washes with increasing stringency $(2 \times, 1 \times, 0.5 \times \mathrm{SSC})$. Finally, the sections were placed in $0.1 \times \mathrm{SSC}$ at $70^{\circ} \mathrm{C}$ for 1 $\mathrm{h}$, rinsed in distilled water, dehydrated in a graded series of alcohol, and exposed to X-ray film.

\section{Combined in situ hybridization and immunohistochemistry}

To examine whether AdipoR1 mRNA is colocalized with 5HT neurons in the DRN, we performed in situ hybridization to detect AdipoR1 mRNA in combination with immunohistochemistry to detect TPH2, a marker of 5-HT neurons [24]. Mouse AdipoR1 cDNA fragments were amplified by RT-PCR using the primers as follows: forward: $5^{\prime}$ GGGATGTTCTTCCTGGGCGCGGTGCTCTGCCT- $3^{\prime}$ and reverse: 5'-ACTCCTGCTCTTGTCTGCCGGTGCTTGGGA GTGG- ${ }^{\prime}$. These PCR amplified fragments were cloned into pBluescriptSKII+ vector. AdipoR1 cRNA probes were labeled with digoxigenin-11-UTP (Sigma-Aldrich, ST. Louis, MO, USA) using standard transcription methods. The brain sections were hybridized with a 1:1 mixture of the labeled cRNA probes at $55^{\circ} \mathrm{C}$ overnight and subsequently rinsed in $2 \times \mathrm{SSC}$, treated with RNase A $(200 \mu \mathrm{g} / \mathrm{ml})$ for $1 \mathrm{~h}$ at $37^{\circ} \mathrm{C}$, and washed in $2 \times, 1 \times, 0.5 \times$, and $0.1 \times \mathrm{SSC}$ (for 5 min each), followed by a final rinse in $0.1 \times \mathrm{SSC}$ at $65^{\circ} \mathrm{C}$ for $1 \mathrm{~h}$. Then, brain sections were treated with $2 \%$ hydrogen peroxide in $0.05 \mathrm{M}$ phosphate-buffered saline (PBS) for 30 min followed by incubation with a blocking solution (PerkinElmer) for $1 \mathrm{~h}$ and a sheep anti-digoxigenin antibody conjugated to horseradish peroxidase (HRP; Roche, Basel, Switzerland) overnight in a humidified chamber. The sections were rinsed in PBS and then incubated with anti-TPH2 antibody (1:400, ab184505, Abcam, Cambridge, UK) overnight in a humidified chamber, followed by incubation with Alexa Fluor 488 goat anti-rabbit IgG secondary antibody (1:400; Molecular Probes, Eugene, OR, USA) for $4 \mathrm{~h}$ and the TSA Plus cyanine 5 tyramide amplification reagent (PerkinElmer, Waltham, MA) for 20 min. After rinsing, the slides were coverslipped immediately with the ProLong Gold antifade reagent (Invitrogen, Carlsbad, California, USA). Signal specificity was ensured either by hybridization with sense-strand probes or pretreatment of brain sections with RNase A $\left(200 \mu \mathrm{g} / \mathrm{ml}\right.$ at $37^{\circ} \mathrm{C}$ for $\left.1 \mathrm{~h}\right)$. The colocalization of AdipoR1 mRNA and TPH2 protein was evaluated in the raphe nuclei using a fluorescence microscope. Neurons from three brain sections containing the DRN of each animal were counted.

\section{Western blot assay}

The dissected brain tissue samples (mPFC, hippocampus and DRN) were homogenized in a lysis buffer containing $50 \mathrm{mM}$ Tris-HCl buffer, $150 \mathrm{mM} \mathrm{NaCl}, 1 \%$ Triton X-100, $1 \%$ sodium deoxycholate, $0.1 \%$ sodium dodecyl sulfate (SDS), phenylmethylsulfonyl fluoride, and PhosSTOP 
Phosphatase Inhibitor Cocktail (Roche Applied Science, Penzberg, Germany). The denatured protein was separated on a SDS-polyacrylamide gel electrophoresis and transferred to polyvinylidene fluoride membrane. The membrane was blocked in a solution of tris-buffered saline with $1 \%$ dried milk and $0.1 \%$ tween 20 , and then incubated with the following primary antibodies diluted in a blocking solution: anti-TPH2 antibody (1:1000; ab184505, Abcam, Cambridge, UK), anti-SERT antibody (1:1000; ab172884, Abcam, Cambridge, UK), anti- $\beta$-actin antibody (1:1000, \#4970, Cell Signaling Technology, Danvers, MA, USA). After washing, the membrane was incubated with IRDye 680LT donkey anti-rabbit IgG secondary antibodies (1:5000; 926-68023, Li-COR Biosciences, Lincoln, NE, USA). The fluorescence was visualized and analyzed using an Odyssey Infrared Imaging System (Li-COR Biosciences, Lincoln, NE, USA).

\section{Immunofluorescence histochemistry and semi- quantitative assessment}

Mice were transcardially perfused with $4 \%$ paraformaldehyde. The brains were removed, postfixed overnight and then transferred to $30 \%$ sucrose and cut into $40-\mu \mathrm{m}$ coronal sections. Immunohistochemistry was performed to detect TPH2, SERT, and 5-HT in the raphe nuclei and 5-HT in the PFC and hippocampus. Briefly, brain sections were rinsed three times in PBS, and incubated in a blocking buffer (1\% bovine serum albumin, $3 \%$ goat serum, $0.3 \%$ Triton $\mathrm{X}-100$ in PBS) for $1 \mathrm{~h}$. The sections were then incubated with antiTPH2 (1:400, ab184505, Abcam, Cambridge, UK), antiSERT (1:200, ab130130, Abcam), and anti-5-HT (1:400; S5545, Sigma, Saint Louis, USA) overnight, respectively. After washing in PBS, sections were incubated for $4 \mathrm{~h}$ with Alexa Fluor 488 goat anti-rabbit IgG secondary antibody (1:400; Molecular Probes, Eugene, OR, USA) at room temperature. Finally, the sections were washed in PBS, mounted onto poly-lysine-coated glass slides, coverslipped with fluorescence mounting medium and visualized using an Olympus confocal microscope (Olympus, Shinjuku, Tokyo, Japan). We analyzed immunofluorescence intensity in the DRN, mPFC and hippocampus using ImageJ (http:// imagej.nih.gov/ij/) and counted the number of cells immunopositive for SERT, TPH2, and 5-HT in 3-5 sections (DRN and mPFC) or 7-8 sections (hippocampus) from each brain spaced every $120 \mu \mathrm{m}$ from approximately -4.36 to $-4.96 \mathrm{~mm}$ for the DRN, from 1.34 to $1.98 \mathrm{~mm}$ for the $\mathrm{mPFC}$ and every $240 \mu \mathrm{m}$ from -1.34 to $-3.64 \mathrm{~mm}$ for the hippocampus relative to bregma. The immunopositive cells were counted manually by experimenters who were blind to the genotypes. Images of immunofluorescence staining were converted to grayscale and the signal intensity of immuolabeling in the DRN, mPFC, and hippocampus was quantified as integrated density using the ImageJ software. The mean gray values were calculated as: [integrated density - (measured area $\times$ mean background signal)]/ measured area. The background signals were measured in areas without signal. The densities were averaged across the sections from each brain and expressed as a percentage relative to the control group mean.

\section{Behavioral and stress procedures}

All behavioral procedures were performed in the late light cycle except sucrose and saccharin preference tests that were measured in the first $2 \mathrm{~h}$ in the dark cycle. The behaviors of each mouse were scored by experimenters who were blind to the genotypes or treatment conditions. Mice were subjected to multiple behavioral tests spaced at least 3 days apart to decrease possible carry-over effects from prior tests.

\section{Chronic unpredictable stress (CUS)}

Mice were subjected to two different stressors daily at different times of the day and housed singly for five consecutive days [39]. The stressors included 2-h restraint, 15-min tail pinch, 24-h constant light, 24-h wet bedding, and $45^{\circ}$ cage tilt, 10-min inescapable foot shocks, 30-min elevated platform, and social isolation. Stress exposure was conducted in a procedure room. Control mice were handled daily.

\section{Female urine sniffing test}

This test was used to assess sex-related reward-seeking behavior based upon interest of male rodents in pheromonal odors from estrus female urine [39, 42]. Female mice were maintained in a separate room, and the estrous cycle was assessed by microscopic evaluation of vaginal smears as previously described [43]. Urine from estrus female mice was collected and stored on ice before use. One hour before the test, mice were habituated to a sterile cotton-tipped applicator inserted into their home cage. For the test, mice were transferred to a dimly-lit room (about 3 lux lighting). The test had three phases: (1) one exposure $(3 \mathrm{~min})$ to the cotton tip dipped in sterile water; (2) a 45-min interval; and (3) one exposure ( $3 \mathrm{~min}$ ) to a cotton tip applicator infused with fresh urine $(80 \mu \mathrm{L})$ collected from female mice of the same strain in estrus. Sniffing time was recorded during exposure to water and female urine.

\section{Saccharin/sucrose preference test}

Mice were habituated to drinking water from two bottles for 1 week before testing. Mice were provided with a free 
choice between a bottle containing $1 \%$ sucrose or $0.01 \%$ saccharin solution and a bottle of plain water. Water and saccharin/sucrose intake was measured during the first $2 \mathrm{~h}$ after lights off in the dark cycle. The preference for sucrose or saccharin solution was calculated by dividing the mass of sucrose or saccharin solution consumed by the total mass of fluid intake. For mice subjected to 5 days of chronic unpredictable stress, sucrose preference test was performed $24 \mathrm{~h}$ after the last stressor.

\section{Forced swim test}

Mice were placed in a clear Plexiglas cylinder $(25 \mathrm{~cm}$ high; $10 \mathrm{~cm}$ in diameter) filled with $24^{\circ} \mathrm{C}$ water to a depth of 15 $\mathrm{cm}$. A charge-coupled device (CCD) camera positioned directly above the cylinder was used to record the behavior of each mouse for $6 \mathrm{~min}$. The duration of immobility in the last $4 \mathrm{~min}$ was measured. Immobility was defined as no movement except those caused by respiration [40].

\section{Locomotor activity}

The locomotor activity was measured in an open-field box $(40 \times 40 \times 40 \mathrm{~cm})$. Mice were placed in the open-field area and allowed to freely explore for $30 \mathrm{~min}$ [39, 40]. A CCD camera was mounted above the open box for recording locomotor activity. The total distance traveled was measured in 2-min bins using Any-maze software (Stoelting, Wood Dale, IL, USA).

\section{Elevated plus-maze test}

The elevated plus-maze test is based on the natural conflict between the animal's drive to explore a new environment and the tendency to avoid a potentially dangerous [44]. The elevated plus-maze consisted of four arms $(35-\mathrm{cm}$ long and 5-cm wide) arranged in the shape of a 'plus' sign and elevated to a height of $70 \mathrm{~cm}$ from the floor. Two arms have no side or end walls (open arms) and the other two arms have side walls and end walls but are open on top (closed arms). The open and closed arms intersect, having a central $5 \times 5-\mathrm{cm}$ square platform giving access to all arms. As described previously [24, 40], mice were placed in the central square facing the corner between a closed arm and an open arm and allowed to explore the elevated plus-maze for $5 \mathrm{~min}$. Their activity was videotaped. The numbers of entries made into each arm and the time spent on the open and closed arms were measured. The approach-avoidance performance was assessed by calculating the percentage of open arm entries (entries into the open arms/total entries into all arms) and percentage of time spent in the open arms (time spent in open arms/total time spent in all arms).

\section{Open-field test}

The apparatus consisted of a $60 \times 60 \mathrm{~cm}$ open arena with 40 $\mathrm{cm}$ high walls. The entire test arena was adjusted to even illumination. Mice were placed in the center of the arena, and their activity was recorded for $5 \mathrm{~min}$. For analysis, the open-field arena was divided into nine equal squares by a $3 \times 3$ grid. The center square was defined as the central zone, in which the animal's activity is usually regarded as a measure of anxiety. The time mice spent in the central zone and the total distance traveled in the open arena were quantified using Any-maze software (Stoelting, Wood Dale, IL, USA). The overall motor activity during the open-field test was assessed as the total distance traveled.

\section{Statistical analyses}

Shapiro-Wilk test and F test were used to test the normality and equal variance assumptions, respectively. For normally distributed data, two-tailed $t$ tests were used to assess differences between two experimental groups with equal variance. For a two-sample comparison of means with unequal variances, two-tailed $t$ tests with Welch's correction were used. For non-normally distributed data, Mann-Whitney U tests were performed to compare two groups. For locomotor activity, forced swim test, and female urine sniffing test, two-way repeated-measures ANOVAs or two-way ANOVAs followed by Bonferroni tests were used. $P<0.05$ was considered statistically significant. All data were presented as mean \pm standard error (s.e.m.).

\section{Results}

\section{Expression of AdipoR1 mRNA in dorsal raphe 5-HT neurons}

Expression of AdipoR1 and AdipoR2 mRNA in the raphe nuclei was examined using in situ hybridization with radioactive cRNA probes. While AdipoR1 mRNA was highly expressed in the DRN, AdipoR2 mRNA was present in very low abundance (Fig. 1a). The degree of colocalization of AdipoR1 and 5-HT neurons in the DRN was assessed using the combined nonradioactive in situ hybridization and immunohistochemical labeling. We found that the vast majority of 5-HT neurons immunoreactive for TPH2 expressed AdipoR1 mRNA in both male and female mice (Fig. 1b; male mice, $97.40 \% \pm 1.33 \%$, total 1289 neurons counted from six brain sections; female mice, $98.80 \% \pm 0.40 \%$, total 1356 neurons counted from six brain sections). This observation provides a neuroanatomical basis for direct action of adiponectin on dorsal raphe 5-HT neurons. 
a

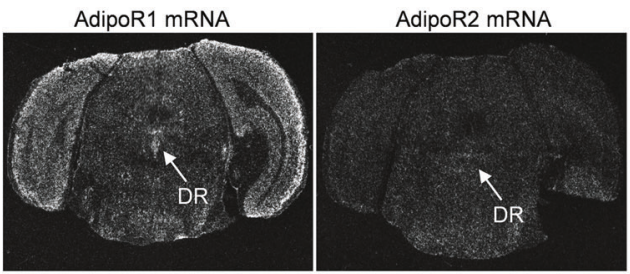

b
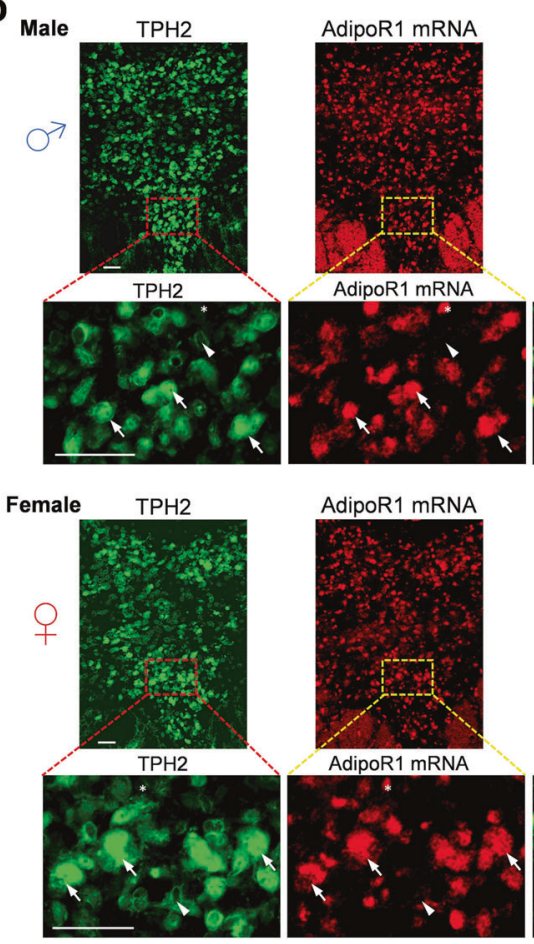

AdipoR1 mRNA
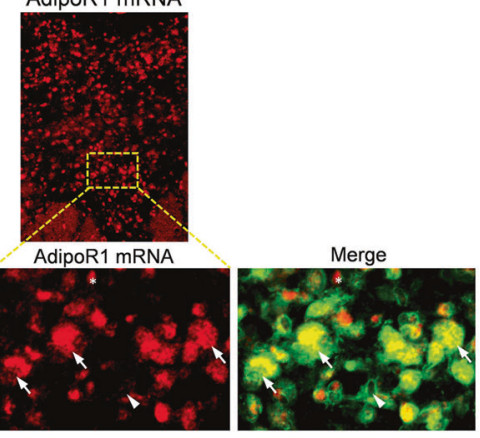

Fig. 1 Expression of AdipoR1 and AdipoR2 in the dorsal raphe nucleus. a In situ hybridization showing expression patterns of AdipoR1 and AdipoR2 mRNA in the dorsal raphe nucleus. b Colocalization of AdipoR1 mRNA and TPH2 protein in the dorsal raphe nucleus on male (upper panel) and female (lower panel) mice. Arrows indicating neurons that contain both AdipoR1 mRNA and TPH2; arrowhead showing neurons that contain only TPH2; asterisk indicating neurons that express only AdipoR1 mRNA only. Scale bar $=50 \mu \mathrm{m}$.

\section{Generation of mice lacking AdipoR1 specifically in 5-HT neurons}

To determine the role of AdipoR1 specifically in 5-HT neurons, we generated 5-HT neuron-specific AdipoR1 knockout mice by crossing homozygous AdipoR $1^{\mathrm{f} / \mathrm{f}}$ mice with ePet-Cre mice [45]. AdipoR $1^{\mathrm{f} / \mathrm{f}}$ mice have loxP sites flanking exon 2 of the AdipoR1 gene [23]. The Pet-1 gene is exclusively expressed in 5-HT neurons [46]. In ePet-Cre mice, Cre recombinase was placed under control of the Pet1 promoter to direct Cre expression to 5-HT neurons [45]. The specificity of ePet-Cre-mediated recombination in 5-HT neurons was confirmed by crossing ePet-Cre mice with the tdTomato reporter line (Ai14) (Fig. 2a), showing that the expression of tdTomato fluorescence was colocalized with the two specific markers for 5-HT neurons, TPH2 $(91.20 \% \pm 0.58 \%$ tdTomato-labeled neurons positive for TPH2; total 1577 neurons counted from three mice) and SERT $(92.20 \% \pm 0.94 \%$ tdTomato-labeled neurons positive for SERT; total 1477 neurons counted from three mice) (Fig. 2b). The male AdipoR $1^{\mathrm{f} /+; \text { ePet-Cre }}$ offspring that resulted from a mating between AdipoR $1^{\mathrm{f} / \mathrm{f}}$ and ePet-Cre mice were backcrossed with female AdipoR $1^{\mathrm{f} / \mathrm{f}}$ to generate AdipoR $1^{\mathrm{f} / \mathrm{f} ; \mathrm{ePt}-\mathrm{Cre}}$ mice and AdipoR $1^{\mathrm{f} / \mathrm{f}}$ littermate controls for the experiments (Fig. 2c, d). Real-time quantitative PCR revealed the deletion of AdipoR1 exon 2 in the DRN of both male and female AdipoR $1^{\mathrm{f} / \text {; } \mathrm{Pet}-\mathrm{Cre}}$ mice (Fig. 2e, male: $t$ test with Welch's correction, $P<0.001$; female: $t_{(10)}=$ $8.985, P<0.001)$.

\section{5-HT neuron-specific AdipoR1 knockout leads to differential behavioral phenotypes in male and female mice}

Sex differences in adiponectin have been reported in both humans and mice [47-49], we therefore assessed the consequences of deletion of AdipoR1 in 5-HT neurons on depression- and anxiety-related behaviors in both male and female mice. Dorsal raphe 5-HT neurons can be rapidly activated by various rewards, including sucrose, food, and sex [50, 51]. First, we determined whether AdipoR1 signaling in 5-HT neurons affects sex-related reward-seeking behavior in male mice using the female urine sniffing test, which is based upon interest of male rodents in pheromonal odors from estrus female urine [42]. We found that male AdipoR $1^{\text {ff; } ; \text { ePet-Cre }}$ mice spent less time sniffing female urine $(P=0.004)$, but showed no difference in water sniffing time as compared with AdipoR $1^{\mathrm{f} / \mathrm{f}}$ mice $(P=0.999)$, indicating an anhedonic-like phenotype (Fig. 3a; genotype, $F_{(1,42)}=6.710, P=0.013$; sniffing object, $\quad F_{(1,42)}=73.450, \quad P<0.001 ; \quad$ genotype $\times$ sniffing object, $\left.F_{(1,42)}=6.870, P=0.012\right)$. Anhedonia can be measured by sucrose preference in both male and female mice [39, 52, 53]. Under basal conditions, neither male nor female AdipoR $1^{\mathrm{f} / \mathrm{f} ; \mathrm{Pet}-\mathrm{Cre}}$ mice showed significant difference in preference for $1 \%$ sucrose solution as compared with their relative control AdipoR $1^{\mathrm{f} / \mathrm{f}}$ mice (Fig. 3b, male: Mann-Whitney test, $P=0.786$; female: $t_{(23)}=0.298, P=$ 0.769). However, when tested using $0.01 \%$ saccharin solution, male AdipoR $1^{\mathrm{f} / \mathrm{f} \text {;ePt-Cre }}$ mice exhibited a reduced preference (Fig. 3c, male: $t_{(21)}=2.710, P=0.013$; female: Mann-Whitney test, $P=0.345$ ). Female but not male AdipoR1 $1^{\text {f/;ePet-Cre }}$ mice exhibited increased behavioral despair, as indicated by increased immobility in the forced swim test (Fig. 3d, male: $t_{(20)}=0.483, P=0.634$; female: $\left.t_{(23)}=2.130, P=0.044\right)$. No genotype difference in baseline locomotion was observed in either sex (Fig. 3e, male: genotype, $F_{(1,21)}=0.205, P=0.655$; time, $F_{(14,294)}=3.020$, 


\section{a}

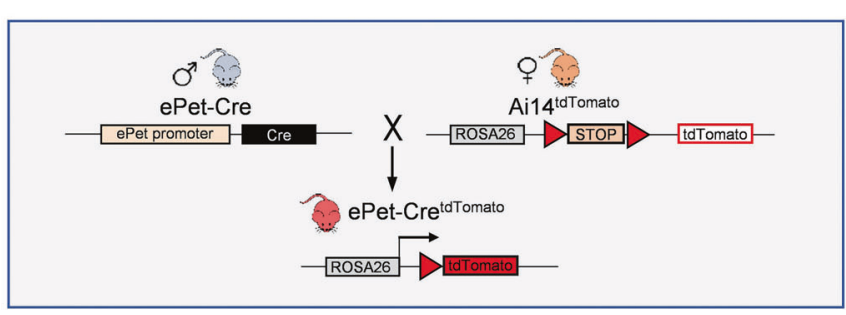

b
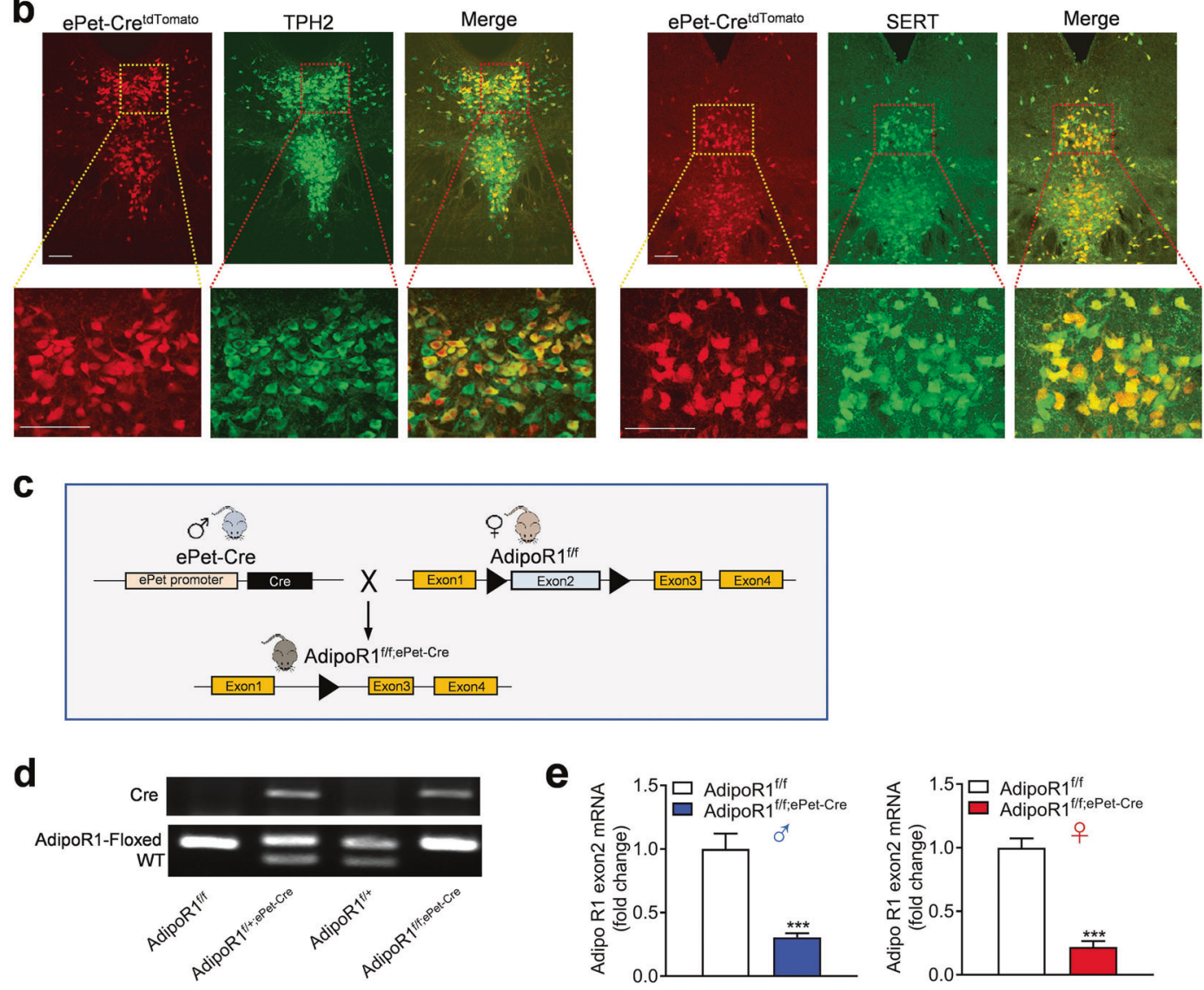

Fig. 2 Generation of mice lacking AdipoR1 specifically in 5-HT neurons. a Schematic diagram of the strategy used for generation of ePet-Cre ${ }^{\text {tdTomato }}$ reporter mice. b (Left panel) Representative coronal sections showing colocalization of tdTomato (red) and tryptophan hydroxylase 2 (TPH2, green) in the dorsal raphe nucleus. (Right panel) Representative coronal sections showing colocalization of tdTomato (red) and serotonin transporter (SERT, green). Scale bar $=100 \mu \mathrm{m}$. c Schematic diagram of generation of mice with selective deletion of AdipoR1 in 5-HT neurons. d PCR results of genotyping. e Real-time PCR analysis showing Cre-mediated deletion of exon 2 of AdipoR1 in the dorsal raphe nucleus of male and female AdipoR $1^{\mathrm{f} / \mathrm{f} \text {;ePet-Cre }}$ mice. Male: AdipoR1 $1^{\mathrm{f} / \mathrm{f}}: n=7$; AdipoR1 ${ }^{\mathrm{f} / \mathrm{f} ; \mathrm{PPt}-C r e}: n=6$, Female: AdipoR $1^{\mathrm{f} / \mathrm{f}}$ : $n=6 ; \quad$ AdipoR $1^{\mathrm{f} / \mathrm{f} ; \mathrm{Pet}-\mathrm{Cre}}: \quad n=6 . \quad * * * P<0.001 \quad$ compared with AdipoR $1^{\mathrm{f} / \mathrm{f}}$ littermate controls.
$P<0.001 ;$ genotype $\times$ time, $\quad F_{(14,294)}=0.798, \quad P=0.671$; total distance: $\left.t_{(21)}=1.090, P=0.288\right)$; female: genotype, $F_{(1,23)}=0.048, \quad P=0.828$; time: $F_{(14,322)}=18.810, P<$ 0.001 ; genotype $\times$ time, $F_{(14,322)}=2.239, P=0.007$; total distance: $\left.t_{(23)}=0.220, P=0.828\right)$. To determine whether loss of AdipoR1 in 5-HT neurons increases susceptibility to stress, male and female mice were exposed to 5 days of CUS. Sucrose preference was significantly reduced in both male and female AdipoR1 $1^{\mathrm{f} / \text {; } \mathrm{ePet}-\mathrm{Cre}}$ mice exposed to 5 days of CUS when compared with AdipoR $1^{\mathrm{f} / \mathrm{f}}$ control mice (Fig. 3f, male: $t_{(14)}=2.175, P=0.047$; female: $t$ test with Welch's correction, $P=0.020$ ), while increased immobility in the forced swim test was only seen in female but not male mice (Fig. 3f, male: Mann-Whitney test, $P=$ 0.999; female: $\left.t_{(21)}=2.404, P=0.025\right)$. These results indicate that loss of AdipoR1 in 5-HT neurons results in differential changes in depression-related behaviors in male and female mice.

Although controversial, studies have shown that 5-HT neurons in the raphe nuclei modulate anxiety behaviors 
a Female urine sniffing test

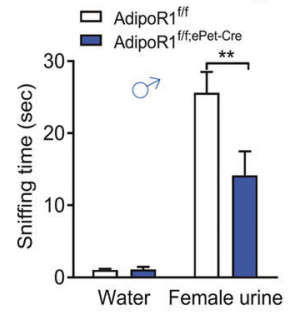

d Forced swim test

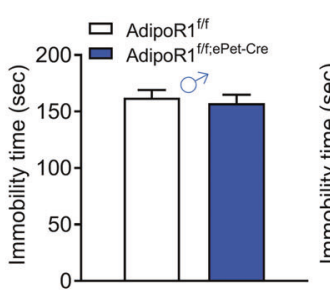

Sucrose preference test

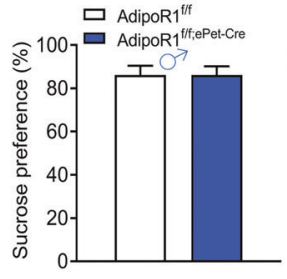

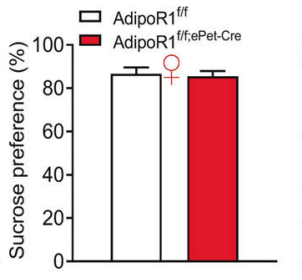

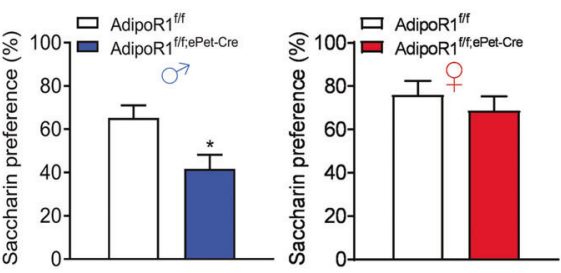

f Sucrose preference test after 5-day CUS

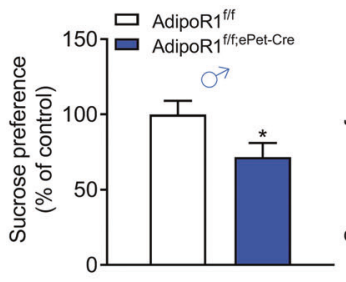

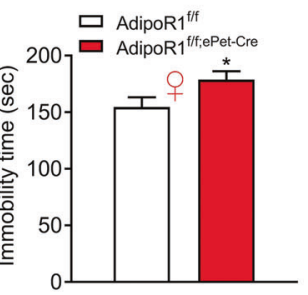

e Locomotor activity

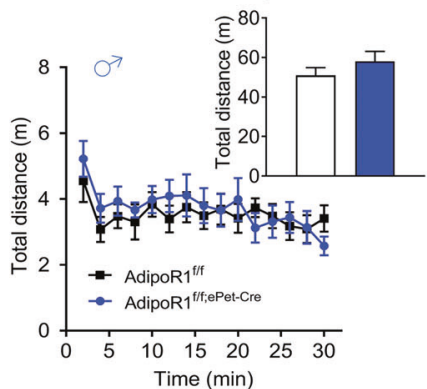

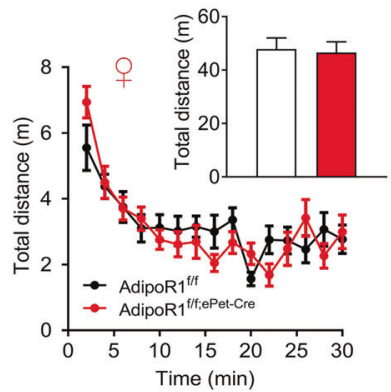

Forced swim test after 5-day CUS
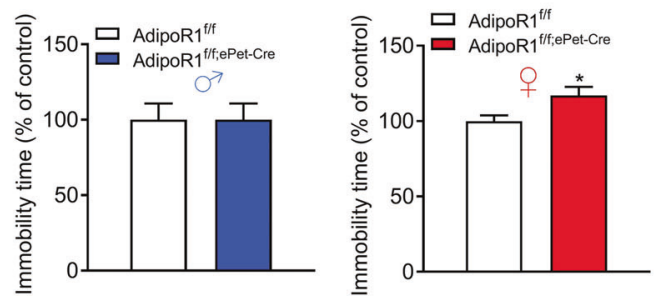

9 Elevated plus maze
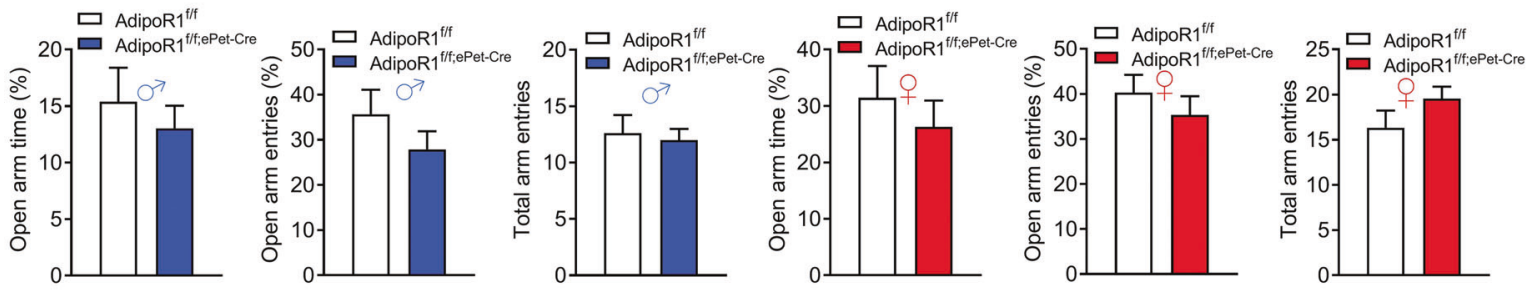

h Open field
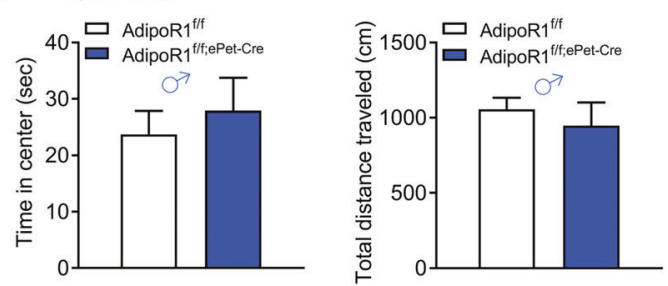

[54-57]. To determine whether AdipoR1 in 5-HT neurons regulate anxiety-related behaviors, we employed the approach-avoidance conflict tests. Avoidance of potential threats and dangerous situations at the cost of approach opportunities is a hallmark feature of anxious disorders. Male and female AdipoR $1^{\mathrm{f} / \mathrm{f} ; \mathrm{ePet}-\mathrm{Cre}}$ and AdipoR $1^{\mathrm{f} / \mathrm{f}}$ mice were assessed using the elevated plus-maze test. The percentage of open arm time, the percentage of open arm entries, total arm entries showed no genotype difference in
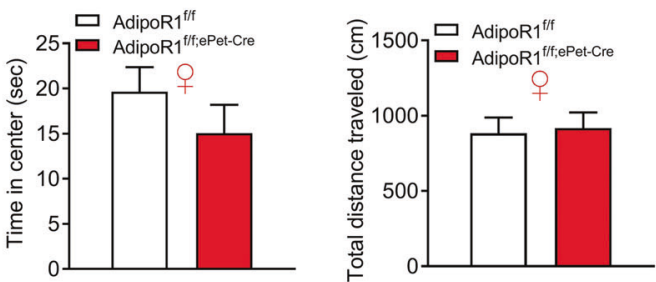

both male and female mice (Fig. 3g, male: percentage of open arm time, $t_{(17)}=0.673, P=0.532$; percentage of open arm entries, $t_{(17)}=1.414, P=0.270$; total arm entries, $t_{(17)}=0.310, P=0.761$; female: percentage of open arm time, $t_{(16)}=0.707, P=0.490$; percentage of open arm entries, $t_{(16)}=0.865, P=0.400$; total arm entries, $t_{(16)}=$ $1.406, P=0.179)$. In the open-field test, neither male nor female mice showed significant genotype difference in time spent in the central zone and total distance traveled (Fig. 3h; 
Fig. 3 Selective deletion of AdipoR1 in 5-HT neurons induces depression-related behaviors. a Female urine sniffing test, AdipoR $1^{\mathrm{f} / \mathrm{f}}$, $n=12 ;$ AdipoR $1^{\mathrm{f} / \mathrm{f} ; \mathrm{Pet}-\mathrm{Cre}}, n=11$. b Sucrose preference test. Left, male mice, AdipoR $1^{\mathrm{f} / \mathrm{f}}, n=12 ;$ AdipoR1 $1^{\mathrm{f} / \mathrm{F} ; \mathrm{Pet}-\mathrm{Cre}}, n=11$. Right, female mice, AdipoR $1^{\mathrm{f} / \mathrm{f}}, n=11$; AdipoR $1^{\mathrm{ff} / \mathrm{i} \text { Pet-Cre }}, n=14$. c Saccharin preference test. Left, male mice, AdipoR $1^{\mathrm{f} / \mathrm{f}} n=12$; AdipoR $1^{\mathrm{f} / \mathrm{f} ; \mathrm{ePet}-\mathrm{Cre}}$, $n=11$. Right, female mice, AdipoR $1^{\mathrm{f} / \mathrm{f}}, n=11$; AdipoR ${ }^{\mathrm{f} / \mathrm{f} ; \mathrm{ePet}-\mathrm{Cre}}$, $n=14$. d Forced swim test. Left, male mice, AdipoR $1^{\mathrm{f} / \mathrm{f}}, n=12$; AdipoR $1^{\mathrm{f} / \mathrm{f} ; \text { Pet-Cre }}, n=10$. Right, female mice, AdipoR $1^{\mathrm{f} / \mathrm{f}}, n=11$; AdipoR $1^{\mathrm{f} / \mathrm{f} \text { ePet-Cre }}, n=14$. e Locomotor activity. The time course of locomotor activity of male (left) and female (right) mice. The inserts indicating the total distance traveled during the 30-min test. Male mice, AdipoR $^{1 / f / f}, n=12$; AdipoR $1^{\mathrm{f} / f ; e P e t-C r e}, n=11$. Female mice, AdipoR $1^{\mathrm{f} / \mathrm{f}}$, $n=11$; AdipoR1 $1^{\mathrm{f} / \mathrm{f} \text { :Pet-Cre }}, n=14$. f (Left and middle-left) Sucrose preference test performed on mice after 5-day CUS. Male mice: AdipoR $1^{\mathrm{f} / \mathrm{f}}$, $n=8 ;$ AdipoR $1^{\mathrm{f} / \mathrm{f} ; \mathrm{ePet}-\mathrm{Cre}}, \quad n=8$. Female mice: AdipoR $1^{\mathrm{f} / \mathrm{f}}, n=11$; AdipoR1 ${ }^{\text {fff;ePet-Cre }}, n=12$. (Middle-right and right) Forced swim test. Male mice: AdipoR $1^{\mathrm{f} / \mathrm{f}}, n=8$; AdipoR $1^{\mathrm{f} / \mathrm{f} \text { ePet-Cre }}, n=8$. Female mice: AdipoR $1^{\mathrm{f} / \mathrm{f}}, n=11$; AdipoR $1^{\mathrm{f} / f ; \mathrm{Pet}-\mathrm{Cre}}, n=12$. g Elevated plus-maze test performed on male (left panel) and female (right panel) mice. Male mice: AdipoR $1^{\mathrm{f} / \mathrm{f}}, n=10$; AdipoR $1^{\mathrm{f} / \mathrm{f} ; \mathrm{ePet}-\mathrm{Cre}}, n=9$. Female mice: AdipoR $1^{\mathrm{f} / \mathrm{f}}$, $n=9 ;$ AdipoR $1^{\mathrm{f} / f ; \mathrm{Pet}-\mathrm{Cre}}, n=9$. h Open-field test performed on male (left panel) and female (right panel) mice. Male mice: AdipoR $1^{\mathrm{f} / \mathrm{f}}, n=$ 10; AdipoR $1^{\mathrm{f} / \mathrm{f} ; \mathrm{ePet}-\mathrm{Cre}}, \quad n=9$. Female mice: AdipoR $1^{\mathrm{f} / \mathrm{f}}, \quad n=10$; AdipoR1 $1^{\mathrm{f} / \mathrm{f} \text {; Pet-Cre }}, n=8 . * P<0.05, * * P<0.01$ compared with AdipoR $1^{\mathrm{f} / \mathrm{f}}$ littermate controls.

male mice: time in the central zone, $t_{(17)}=0.596, P=$ 0.559; total distance traveled, $t_{(17)}=0.654, P=0.522$; female mice: time in the central zone, $t_{(16)}=1.110, P=$ 0.284 ; total distance traveled, $t_{(16)}=0.225, P=0.825$ ).

\section{Alterations in expression of key components of the 5-HT system induced by deletion of AdipoR1 in 5-HT neurons in both male and female mice}

A functional 5-HT system in the brain requires endogenous 5-HT synthesis by TPH2 [58, 59] and reuptake of 5-HT by SERT [60], which constitute two essential functions of mature 5-HT neurons for proper 5-HT neurotransmission. We therefore determined expression levels of TPH2, SERT as well as 5-HT in the DRN and two projection fields of raphe 5-HT neurons.

In the DRN, loss of AdipoR1 in 5-HT neurons did not affect SERT protein levels in either male or female mice (Fig. 4a, male, $t_{(10)}=0.180, P=0.861$; female, $t_{(10)}=$ $0.582, P=0.573)$. Interestingly, TPH2 protein levels were decreased in male AdipoR $1^{\mathrm{f} / \mathrm{f} \text { ePet-Cre }}$ mice (Fig. 4a, $t_{(10)}=$ 3.487, $P=0.006)$, but not significantly altered in female AdipoR $1^{\mathrm{f} / \mathrm{f} ; \mathrm{ePet}-\mathrm{Cre}}$ mice $\left(t_{(10)}=1.654, \quad P=0.129\right)$ when compared with AdipoR $1^{\mathrm{f} / \mathrm{f}}$ mice. We further analyzed SERT, TPH2, and 5-HT immunoreactivity in male mice. The number of SERT-immunopositive cells and total fluorescence intensity in the DRN showed no genotype differences (Fig. 4b, fluorescence intensity: $t_{(4)}=0.234$, $P=0.827$; cell number: $t_{(4)}=0.773, P=0.483$ ). By contrast, the numbers of TPH2- and 5-HT-immunopositive cells and fluorescence intensity of TPH2 and 5-HT were significantly decreased by the deletion of AdipoR1 in 5-HT neurons (Fig. 4b; TPH2: fluorescence intensity: $t_{(4)}=3.578$, $P=0.023$; cell number: $t_{(4)}=3.367, P=0.028 ; 5-\mathrm{HT}$ : fluorescence intensity: $t_{(4)}=3.102, P=0.036$; cell number: $\left.t_{(4)}=3.061, P=0.038\right)$.

In the two DRN projection fields, i.e., hippocampus and mPFC, SERT protein expression and 5-HT immunoreactivity were examined. Protein levels of SERT were increased in both the mPFC and hippocampus of male AdipoR $1^{\mathrm{f} / f ; \mathrm{ePet}-\mathrm{Cre}}$ mice (Fig. 5a, b; mPFC: $t_{(10)}=2.549$, $P=0.029$; hippocampus: $\left.t_{(10)}=2.969, P=0.014\right)$ but only in the $\mathrm{mPFC}$ of female AdipoR $1^{\mathrm{f} / \mathrm{f} \text { ePet-Cre }}$ mice when compared with AdipoR $1^{\mathrm{f} / \mathrm{f}}$ mice (Fig. 5a, b; mPFC: $t_{(12)}=2.912$, $P=0.013$; hippocampus: SERT: $\left.t_{(12)}=1.616, P=0.132\right)$. In consistence with the reduced TPH2 and 5-HT levels in the DRN, 5-HT immunofluorescence intensity was significantly decreased in the $\mathrm{mPFC}$ and hippocampus of male AdipoR $1^{\mathrm{f} / \mathrm{f} ; \mathrm{ePet}-\mathrm{Cre}}$ mice (Fig. 5a, b; mPFC: $t_{(4)}=3.072, P=$ 0.037; hippocampus: $t_{(4)}=2.966, P=0.041$ ), while female AdipoR $1^{\mathrm{f} / \mathrm{f} \text { :Pet-Cre }}$ mice showed no change (Fig. 5a, b; mPFC: $t_{(4)}=0.127, P=0.905$; hippocampus: $t_{(4)}=0.207$, $P=0.847)$, compared with AdipoR ${ }^{\mathrm{f} / \mathrm{f}}$ mice.

\section{Loss of AdipoR1 signaling in 5-HT neurons enhances the antidepressant response to the SSRI fluoxetine}

Given the alterations in SERT and TPH2 in the DRN and its projection fields, we next examined the effects of AdipoR1 deletion in 5-HT neurons on antidepressant-like behavioral responses to fluoxetine, a SSRI, in comparison with desipramine, a potent inhibitor of the reuptake of norepinephrine, with little effect on 5-HT reuptake [29, 61]. In the forced swim test, two-way ANOVA revealed significant effects of genotype $\left(F_{(1,55)}=15.830, P<0.001\right)$, treatment $\left(F_{(3,55)}=18.590\right.$, $P<0.001)$ and genotype $\times$ treatment interaction $\left(F_{(3,55)}=\right.$ $3.020, P=0.037)$ on immobility time in male mice. A lower dose of fluoxetine $\left(5 \mathrm{mg} \mathrm{kg}^{-1}\right)$ failed to alter immobility time in male AdipoR $1^{\mathrm{f} / \mathrm{f}}$ control mice $(P=0.738)$, but significantly decreased immobility time in male AdipoR $1^{\mathrm{f} / \mathrm{f} ; \mathrm{ePet}-\mathrm{Cre}}$ mice $(P<0.001)$. A higher dose of fluoxetine $\left(10 \mathrm{mg} \mathrm{kg}^{-1}\right)$ and desipramine $\left(10 \mathrm{mg} \mathrm{kg}^{-1}\right)$ significantly reduced immobility time in both male AdipoR $1^{\mathrm{f} / \mathrm{f}}$ and AdipoR $1^{\mathrm{f} / \mathrm{f} ; \mathrm{ePet}-\mathrm{Cre}}$ mice (Fluoxetine-10 $\mathrm{mg} \mathrm{kg}^{-1}$ : AdipoR1 ${ }^{\mathrm{f} / \mathrm{f}}, \quad P=0.048$; AdipoR1 $1^{\mathrm{f} / \mathrm{f} ; \mathrm{ePet}-\mathrm{Cre}}, \quad P<0.001$. Desipramine- $10 \mathrm{mg} \mathrm{kg}^{-1}$ : AdipoR1 ${ }^{\mathrm{f} / \mathrm{f}}, P=0.005$; AdipoR $\left.1^{\mathrm{f} / \mathrm{f} ; \mathrm{ePt}-\mathrm{Cre}}, P=0.002\right)$. Male AdipoR $1^{\mathrm{f} / \mathrm{f} ; \mathrm{Pet}-\mathrm{Cre}}$ mice displayed an enhanced behavioral response to fluoxetine (Fluoxetine $-5 \mathrm{mg} \mathrm{kg}^{-1}: P=0.028$; $\left.10 \mathrm{mg} \mathrm{kg}^{-1}: P=0.009\right)$ but not to desipramine $(P=0.994)$. Female mice showed significant effects of treatment $\left(F_{(2,43)}=\right.$ 18.950, $P<0.001)$ but not genotype $\left(F_{(1,43)}=2.361, P=\right.$ $0.132)$ and genotype $\times$ treatment interaction $\left(F_{(2,43)}=0.601\right.$, $P=0.553)$ on immobility time in the forced swim test. Fluoxetine and desipramine decreased immobility time in 
a
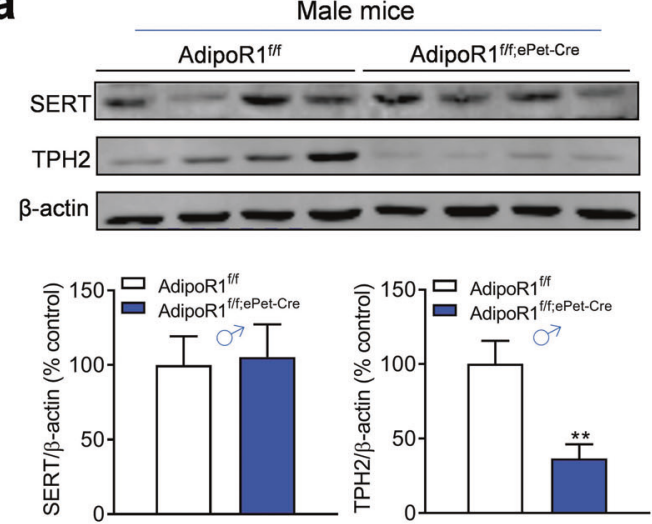
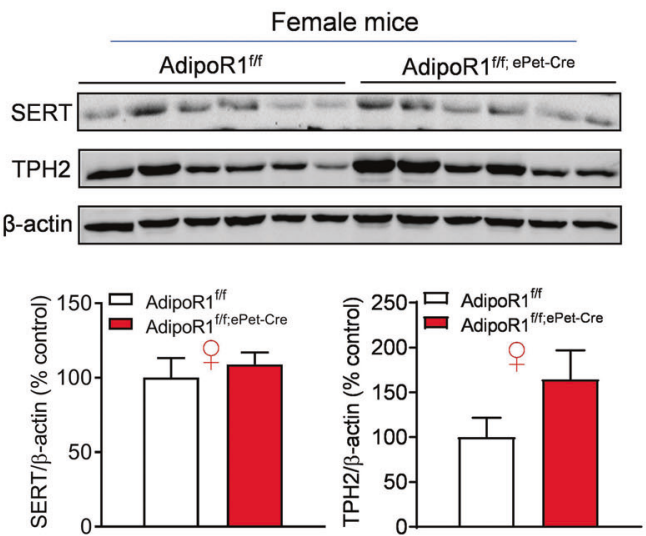

b
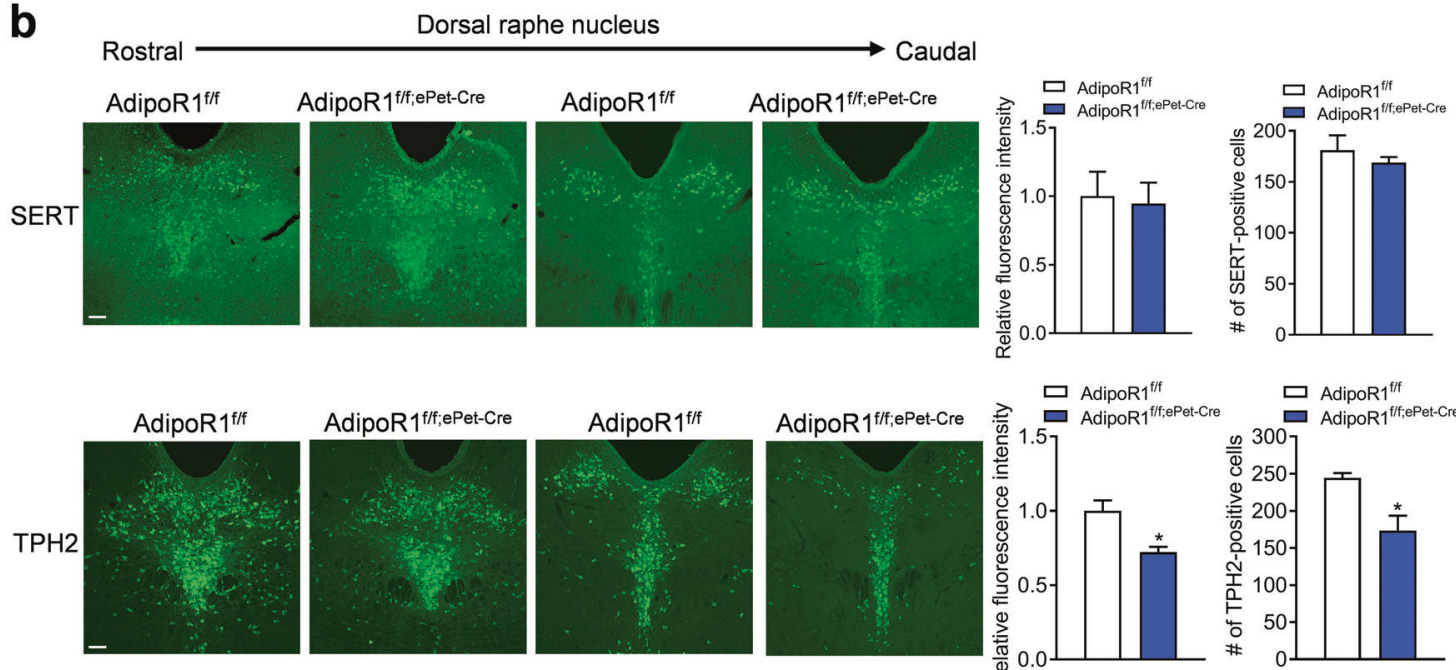

AdipoR $1^{\text {ff }}$
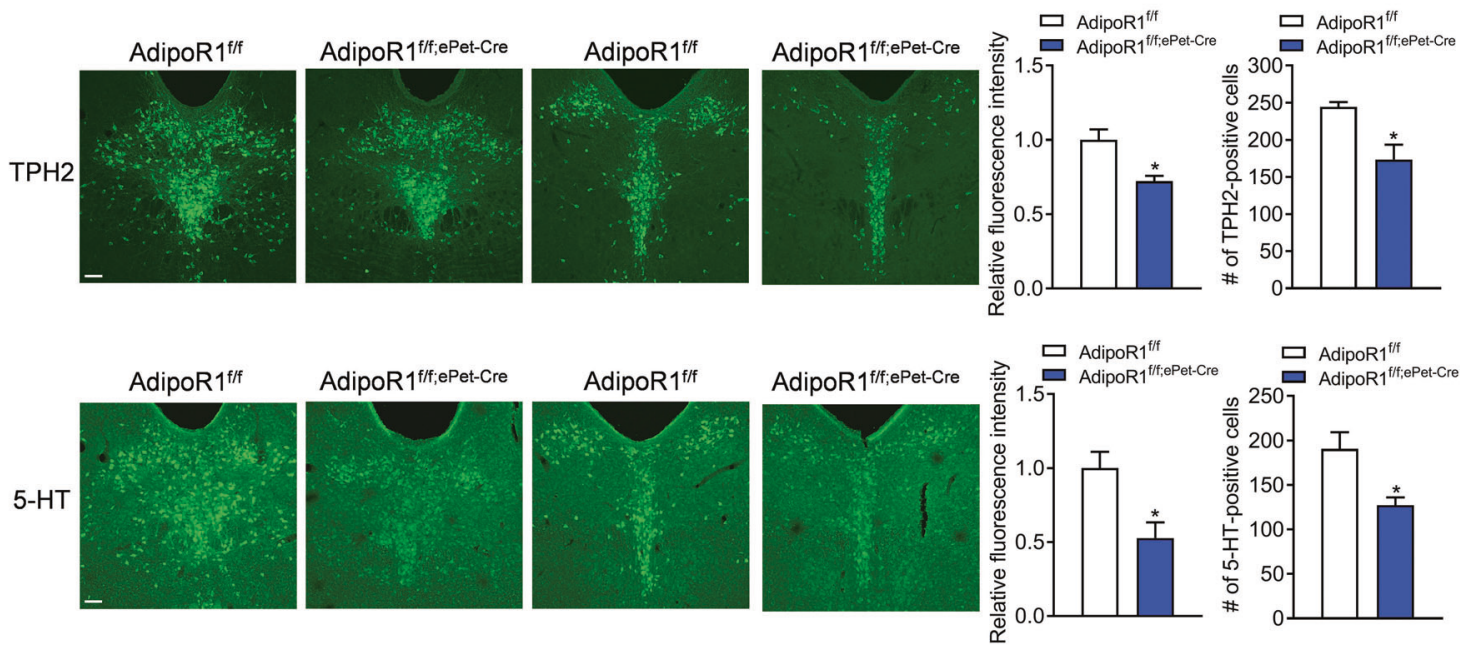

Fig. 4 Effects of selective deletion of AdipoR1 in 5-HT neurons on expression levels of SERT, TPH2 and 5-HT in the dorsal raphe nucleus. a Immunoblots showing SERT and TPH2 protein levels in male (left) and female (right) AdipoR $1^{\mathrm{f} / \mathrm{f}}$ and AdipoR $1^{\mathrm{f} / \mathrm{j} ; \mathrm{ePet}-\mathrm{Cre}}$ mice. Male mice: AdipoR1 ${ }^{\mathrm{f} / \mathrm{f}}, n=6$; AdipoR $1^{\mathrm{f} / \mathrm{f} ; \mathrm{ePet}-\mathrm{Cre}}, n=6$. Female mice: AdipoR $1^{\mathrm{f} / \mathrm{f}}, n=6$; AdipoR1 ${ }^{\mathrm{f} / \mathrm{f} \text {; Pet-Cre }}, n=6$. b (Left panels) Representative immunohistochemical staining showing SERT, TPH2, and 5-HT immunofluorescence in the dorsal raphe nucleus of male AdipoR $1^{\mathrm{f} / \mathrm{f}}$ and AdipoR $1^{\mathrm{f} / \mathrm{f} \text { ePet-Cre }}$ mice. (Middle panels) Relative fluorescence intensity normalized by control mice. (Right panels) The average number of immunopositive neurons per section in the dorsal raphe nucleus. SERT: 12 sections from three AdipoR $1^{\mathrm{f} / \mathrm{f}}$ mice; 12 sections from three AdipoR $1^{\mathrm{f} / f ; \mathrm{ePet}-\mathrm{Cre}}$ mice. TPH2: 11 sections from three AdipoR1 $1^{\mathrm{f} / \mathrm{f}}$ mice; 11 sections from three AdipoR1 ${ }^{\mathrm{f} / \mathrm{f} ; \mathrm{ePet}-\mathrm{Cre}}$ mice. 5-HT: 12 sections from three AdipoR $1^{\mathrm{f} / \mathrm{f}}$ mice; 12 sections from three AdipoR $1^{\text {fff;ePet-Cre }}$ mice. Scale bar $=100 \mu \mathrm{m} . * P<0.05, * * P<0.01$ compared with AdipoR $1^{\mathrm{f} / \mathrm{f}}$ littermate controls. both female AdipoR $1^{\mathrm{f} / \mathrm{f}}$ control mice and AdipoR $1^{\mathrm{f} / \mathrm{f} ; \mathrm{ePet}-\mathrm{Cre}}$ mice (Fluoxetine-10 $\mathrm{mg} \mathrm{kg}^{-1}$ : AdipoR1 ${ }^{\mathrm{f} / \mathrm{f}}, \quad P=0.048$; AdipoR1 $1^{\mathrm{f} / \mathrm{j} \text { ePet-Cre }}, \quad P=0.004$. Desipramine-10 $\mathrm{mg} \mathrm{kg}^{-1}$ : AdipoR $1^{\mathrm{f} / \mathrm{f}}, P=0.019$; AdipoR1 $\left.1^{\mathrm{f} / \mathrm{f} ; \mathrm{ePet}-\mathrm{Cre}}, P<0.001\right)$. However, there was no genotype difference in either fluoxetine $(P=0.989)$ or desipramine treatment $(P=0.999)$ (Fig. $5 c)$.

\section{Discussion}

We have previously shown that adiponectin haploinsufficiency causes depression- and anxiety-related behaviors in mice via a central mechanism of action [21, 24]. The present study provides evidence of 5-HT neurons as a 


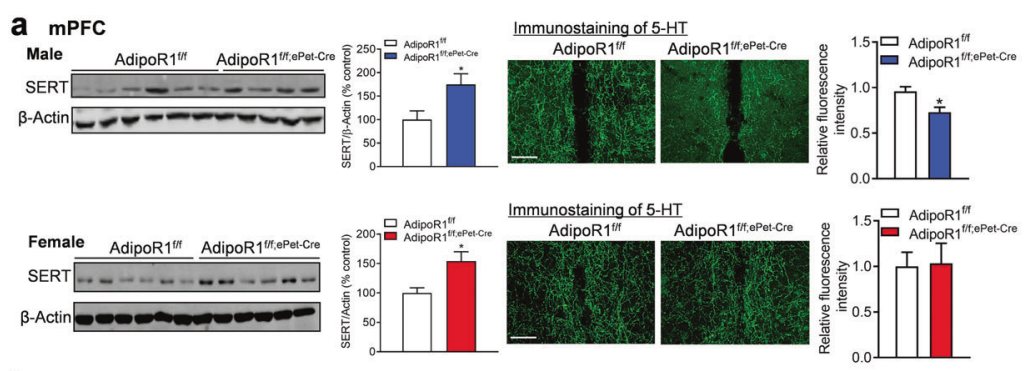

b Hippocampus
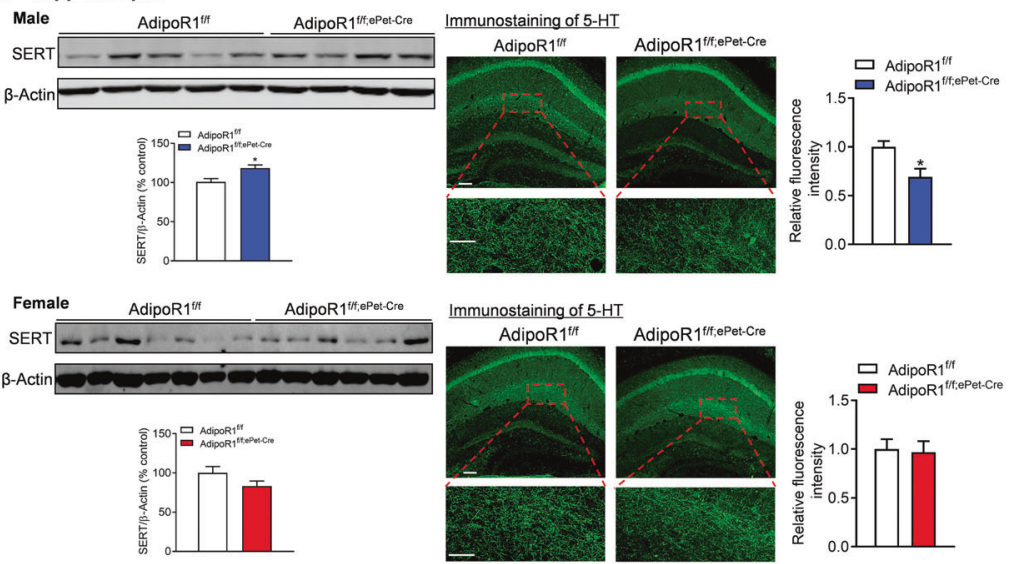

C

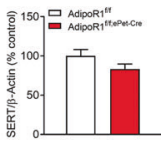

Forced swim test - female mice

Forced swim test - male mice $\square$ Saline

Fluoxetine $\left(5 \mathrm{mg} \mathrm{kg}^{-1}\right)$

$\square$ Desipramine $\left(10 \mathrm{mg} \mathrm{kg}^{-1}\right)$

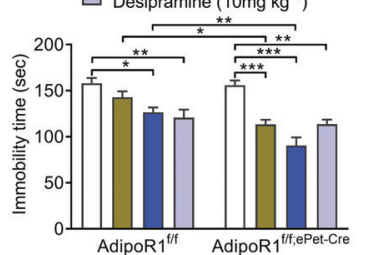

$\square$ Saline

$\square$ Fluoxetine $\left(10 \mathrm{mg} \mathrm{kg}^{-1}\right)$

$\square$ Desipramine $\left(10 \mathrm{mg} \mathrm{kg}^{-1}\right)$

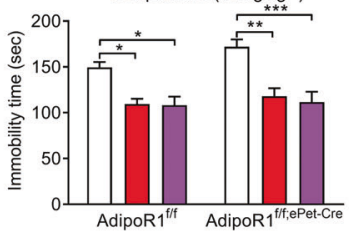

d

Male AdipoR 1/f/:ePet-Cre

Female AdipoR $1^{\text {iffePet-Cre }}$

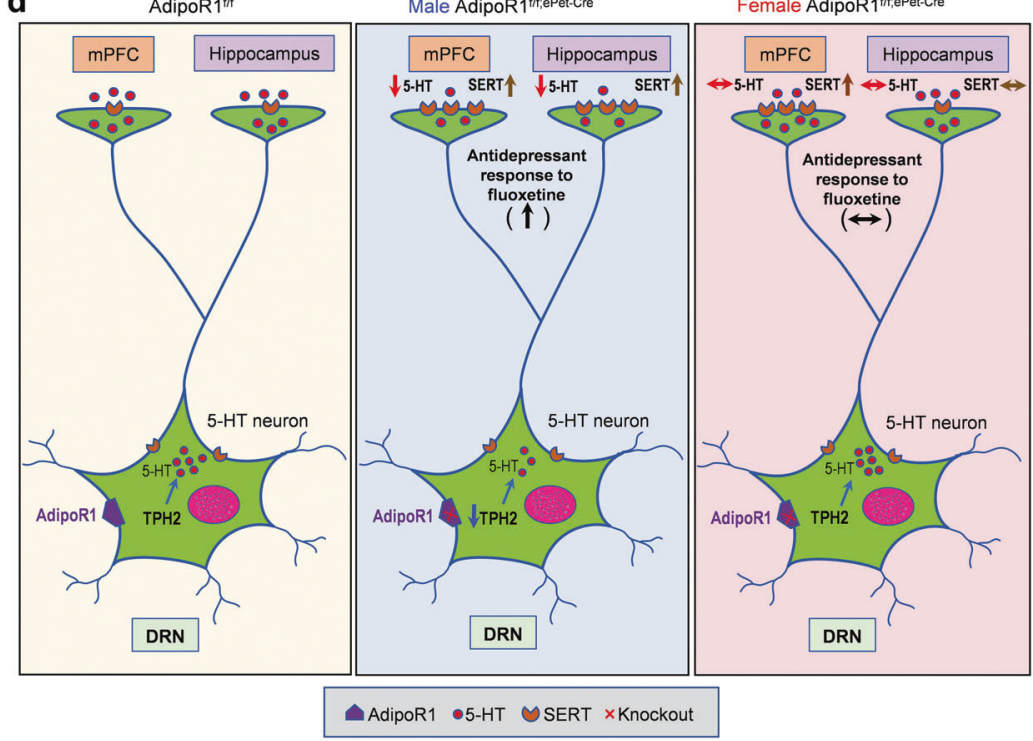

neuronal substrate mediating the effects of adiponectin/ AdipoR1 signaling on depression- but not anxiety-related behaviors. One important finding was that 5-HT neuron- specific AdipoR1 knockout causes differential behavioral phenotypes, stress susceptibility and antidepressant responses in male and female mice. The underlying mechanisms 
Fig. 5 Effects of selective deletion of AdipoR1 in 5-HT neurons on SERT and 5-HT immunoreactivity in MPFC and hippocampus and behavioral responses to fluoxetine and desipramine. a (Left panels) Representative immunoblots and quantitative analysis of SERT levels in the mPFC of male (upper) and female (lower) mice. Male mice: AdipoR $1^{\mathrm{f} / \mathrm{f}}, n=6$; AdipoR $1^{\mathrm{f} / \mathrm{f} \text { ePet-Cre }}, n=6$. Female mice: AdipoR $1^{\mathrm{f} / \mathrm{f}}, n=7$. AdipoR $1^{\mathrm{f} / \mathrm{f} ; \mathrm{Pet}-\mathrm{Cre}}, n=7$. (Right panels) Representative brain sections immunostained for 5-HT and quantitative analysis of the intensity of 5-HT-positive fibers in the mPFC of male (upper) and female (lower) mice. Male: 14 sections from three AdipoR $1^{\mathrm{f} / \mathrm{f}}$ mice; 14 sections from three AdipoR $1^{\mathrm{f} / \mathrm{f} \text { ePet-Cre }}$ mice. Female: 14 sections from three AdipoR $1^{\mathrm{f} / \mathrm{f}}$ mice; 13 sections from three AdipoR $1^{\mathrm{f} / \mathrm{f} ; \mathrm{ePet}-\mathrm{Cre}}$ mice. Scale bar $=50 \mu \mathrm{m}$. b (Left panels) Representative immunoblots and quantitative analysis of SERT levels in the hippocampus of male (upper) and female (lower) mice. Male mice: AdipoR $1^{\mathrm{f} / \mathrm{f}}, n=6$; AdipoR $1^{\mathrm{f} / \mathrm{f} ; \mathrm{Pet}-\mathrm{Cre}}, n=6$. Female mice: AdipoR $1 / f / f^{\mathrm{f}}, n=7$. AdipoR $1^{\mathrm{f} / f ; \mathrm{ePet}-\mathrm{Cre}}, n=7$. (Right panels) Representative brain sections immunostained for 5-HT and quantitative analysis of the intensity of 5-HT-positive fibers in the hippocampus of both male (upper) and female (lower) mice. Male: 24 sections from three AdipoR $1^{\mathrm{f} / \mathrm{f}}$ mice; 23 sections from three AdipoR $1^{\mathrm{f} / \mathrm{f} ; \mathrm{ePet}-\mathrm{Cre}}$ mice. Female: 21 sections from three AdipoR $1^{\mathrm{f} / \mathrm{f}}$ mice; 24 sections from three AdipoR $1^{\mathrm{f} / \text {; } ; \text { Pet-Cre }}$ mice. Scale bar $=100 \mu \mathrm{m}$ for low magnification and $50 \mu \mathrm{m}$ for high magnification. $\mathbf{c}$ Forced swim test performed $30 \mathrm{~min}$ after fluoxetine $\left(5\right.$ or $10 \mathrm{mg} \mathrm{kg}^{-1}$, i.p.) or desipramine $\left(10 \mathrm{mg} \mathrm{kg}^{-1}\right.$, i.p.) injection in male (left) and female (right) mice. Male mice: AdipoR $1^{\mathrm{f} / \mathrm{f}}+$ saline, $n=7 ; \quad$ AdipoR $1^{\mathrm{f} / \mathrm{f}}+$ fluoxetine $\left(5 \mathrm{mg} \mathrm{kg}^{-1}\right), \quad n=9 ; \quad$ AdipoR $1^{\mathrm{f} / \mathrm{f}}+$ fluoxetine $\left(10 \mathrm{mg} \mathrm{kg}^{-1}\right), \quad n=7$; AdipoR $1^{\mathrm{f} / \mathrm{f}}+$ desipramine, $n=9 ;$ AdipoR $1^{\mathrm{f} / \mathrm{f} \text { ePet-Cre }}+$ saline, $n=7$; AdipoR $1^{\mathrm{f} / f ; \mathrm{ePet}-\mathrm{Cre}}+$ fluoxetine $\left(5 \mathrm{mg} \mathrm{kg}^{-1}\right), n=9$; AdipoR $1^{\mathrm{f} / \mathrm{f} ; \mathrm{ePt}-\mathrm{Cre}}+$ fluoxetine $\left(10 \mathrm{mg} \mathrm{kg}^{-1}\right), n=8$; AdipoR $1^{\mathrm{f} / \text {; } \text {;et-Cre }}+$ desipramine, $n=7$. Female mice: AdipoR $1^{\mathrm{f} / \mathrm{f}}+$ saline, $n=8$; AdipoR $1^{\mathrm{f} / \mathrm{f}}+$ fluoxetine, $n=$ 7; AdipoR $1^{\mathrm{f} / \mathrm{f}}+$ desipramine, $n=10$; AdipoR $1^{\mathrm{f} / f ; \mathrm{Pet}-\mathrm{Cre}}+$ saline, $n=7$; AdipoR $1^{\text {f/f;ePet-Cre }}+$ fluoxetine, $n=7$; AdipoR $1^{\mathrm{f} / \mathrm{f} \text { :Pet-Cre }}+$ desipramine, $n=10 . * P<0.05, * * P<0.01, * * * P<0.001$ compared with AdipoR $1^{\mathrm{f} / \mathrm{f}}$ littermate controls or saline-treated groups. d Schematic diagram illustrating the alterations in 5-HT system components and antidepressant responses induced by the loss of AdipoR1 in 5-HT neurons.

seem to involve alterations in the key components of 5-HT transmission. We demonstrated that AdipoR1 is required for normal expression of genes involved in synthesis and reuptake of 5-HT.

It is well recognized that gender differences in depressive symptoms and antidepressant response, the neurobiological basis, however, remains poorly understood. Depressive disorders are more prevalent in people with obesity and diabetes [62-66]. Circulating levels of adiponectin are decreased in obesity and type 2 diabetes [67] and are lower in men than in women $[47,68]$. We have previously shown that social stress reduces plasma adiponectin levels and adiponectin haploinsufficiency increases stress susceptibility in male mice [40]. Female mice appear to be more resilient to stress-induced reduction of adiponectin (data not shown). We speculate that sex differences may exist in the sensitivity of adiponectin receptors expressed in specific neuronal populations. Adiponectin AdipoR1 and AdipoR2 receptors have distinct distribution patterns [21]. While AdipoR1 is widely distributed in the brain, expression of
AdipoR2 is restricted to only few brain regions [21]. Our in situ hybridization data revealed that AdipoR 1 is the predominant receptor that mediates adiponectin actions in the DRN. Furthermore, we demonstrated that AdipoR1 was expressed in the vast majority of 5-HT neurons, suggesting a direct action of adiponectin on DRN 5-HT neurons through AdipoR1. To assess the specific role of AdipoR1 in 5-HT neurons, we used an ePet-Cre transgenic mouse line to delete floxed AdipoR1 specifically in 5-HT neurons [45]. Pet-1 is a precise marker of developing and adult 5-HT neurons $[46,69,70]$. We confirmed that Cre activity in ePet-Cre mice was restricted to 5-HT neurons defined by TPH2 and SERT immunoreactivity. This cell specificity of ePet-Cre transgenic line is an advantage over the SERT-Cre knockin mouse line, in which Cre recombinase is much more widely expressed in the brain and periphery [71]. We found that male mice lacking AdipoR1 in 5-HT neurons displayed reduced sex-related reward-seeking behavior, assessed by the female urine sniffing test. While both male and female conditional knockout mice showed no change in hedonic responses to sucrose under basal conditions, a reduction in the preference for saccharin, a non-caloric sweetener, was observed in male but not female mice. Interestingly, loss of AdipoR1 in 5-HT neurons enhanced stress-induced decrease in sucrose preference in both sexes. The caloric content in sucrose solution and limited palatability of saccharin compared with sucrose may account for differences in the sensitivity to sucrose and saccharin [72]. In addition, female but not male conditional knockout mice exhibited enhanced behavioral despair in the forced swim test. These differences in phenotypic expression between male and female mice are unlikely due to the different degree of AdipoR1 expression in 5-HT neurons or AdipoR1 deletion induced by ePet-Cre as male and female mice have similar AdipoR1 colocalization patterns and comparable extents of AdipoR1 deletion in the DRN.

The mechanisms by which AdipoR1 in 5-HT neurons regulates depression-related behaviors appear to involve regulation of two key components of 5-HT homeostasis, i.e., synthesis and reuptake. 5-HT synthesis is controlled by two isoforms of TPH, TPH1 and TPH2, which catalyzes the rate-limiting reaction in the biosynthesis of 5-HT in the periphery and brain, respectively [58, 73]. TPH 2 is predominantly expressed in 5-HT neurons of the raphe nuclei and converts L-tryptophan into L-5-hydroxytryptophan, a precursor for brain 5-HT synthesis [58, 74]. The role of 5-HT synthesis in the pathophysiology of depression is suggested by the fact that acute tryptophan depletion can induce a depressive state in patients with remitted depression [75]. Furthermore, the findings of low 5-HT and its metabolite 5-HIAA detected in the CSF of suicides and depressed patients indicate a state of brain 5-HT deficiency [76]. Consistently, loss-of-function mutations of TPH2 have 
been associated with susceptibility to major depression and suicidal behavior [36, 77-80]. It has been reported that the mean rate of 5-HT synthesis in normal males is $52 \%$ higher than in normal females [81], but the rate of brain serotonin metabolism is higher in females than in males $[82,83]$. We found that selective deletion of AdipoR1 in 5-HT neurons decreased TPH2 levels in the DRN with concurrent reduction of 5-HT immunoreactivity at the cell body region and two terminal areas, i.e., the mPFC and hippocampus, of male but not female mice. The reduced 5-HT synthesis would result in decreased 5-HT release and transmission. Once released from nerve terminals, the action of 5-HT in the synaptic cleft is terminated primarily by reuptake into presynaptic nerve terminals by SERT that can be inhibited by fluoxetine. While loss of AdipoR1 in 5-HT neurons had no effects on SERT protein expression in the DRN, it increased SERT protein levels in both the MPFC and hippocampus of male mice, but only in the mPFC of female mice. Decreased 5-HT synthesis and/or increased reuptake in male mice presumably lead to deficient 5-HT neurotransmission to different extents in male and female mice. The greater behavioral deficits in male mice may result from the combined effects of decreased synthesis and increased uptake of 5-HT in both the MPFC and hippocampus, while the modest overt phenotypes observed in female mice may be due to increased SERT expression in the mPFC. In consistence with robust increases in SERT levels in multiple brain regions, male mice lacking AdipoR1 in 5-HT neurons showed enhanced antidepressant-like behavioral responses to the serotonin reuptake inhibitor fluoxetine. These results suggest that AdipoR1 receptors are required for regulation of normal 5-HT neurotransmission and dysfunctional AdipoR1 signaling causes depression-related behaviors that are highly responsive to SERT inhibition.

The common behavioral phenotype observed in both male and female mice lacking AdipoR1 in 5-HT neurons is anhedonia. Previous studies have suggested that 5-HT neurons in the DRN encode reward signals [50, 51, 84, 85]. Rewards activate 5-HT neurons [51], and stimulation of 5HT neurons induces self-administration [50] and resembles the natural reward of sucrose [84]. Our data suggest that adiponectin/AdipoR1 signaling plays an important role in reward processing of 5-HT neurons under basal and stress conditions.

In conclusion, our results demonstrate an important role of adiponectin/AdipoR1 signaling in 5-HT neurons in depression-related behaviors and antidepressant responses, which involves in the regulation of key components of 5-HT neurotransmission. These effects are more pronounced in males than females. Our observations provide a basis for a novel mechanism by which dysfunctional adipose tissue-brain crosstalk contributes to mood regulation. Investigations of how AdipoR1 signaling influences 5-HT neuron activity and transmission will reveal new insights into our understanding of mood disorders, especially those conditions that are comorbid with obesity and type 2 diabetes involving adipose tissue dysfunction and hypoadiponectinaemia.

Acknowledgements This work was partially supported by NSFC No. 81601189 (CL) and NIH grant MH100583 (X-YL).

\section{Compliance with ethical standards}

Conflict of interest The authors declare that they have no conflict of interest.

Publisher's note Springer Nature remains neutral with regard to jurisdictional claims in published maps and institutional affiliations.

Open Access This article is licensed under a Creative Commons Attribution 4.0 International License, which permits use, sharing, adaptation, distribution and reproduction in any medium or format, as long as you give appropriate credit to the original author(s) and the source, provide a link to the Creative Commons license, and indicate if changes were made. The images or other third party material in this article are included in the article's Creative Commons license, unless indicated otherwise in a credit line to the material. If material is not included in the article's Creative Commons license and your intended use is not permitted by statutory regulation or exceeds the permitted use, you will need to obtain permission directly from the copyright holder. To view a copy of this license, visit http://creativecommons. org/licenses/by/4.0/.

\section{References}

1. Scherer PE, Williams S, Fogliano M, Baldini G, Lodish HF. A novel serum protein similar to C1q, produced exclusively in adipocytes. J Biol Chem. 1995;270:26746-9.

2. Maeda K, Okubo K, Shimomura I, Funahashi T, Matsuzawa Y, Matsubara K. cDNA cloning and expression of a novel adipose specific collagen-like factor, apM1 (AdiPoseMost abundant Gene transcript 1). Biochem Biophys Res Commun. 1996;221:286-9.

3. Fruebis J, Tsao T-S, Javorschi S, Ebbets-Reed D, Erickson MRS, Yen FT, et al. Proteolytic cleavage product of $30-\mathrm{kDa}$ adipocyte complement-related protein increases fatty acid oxidation in muscle and causes weight loss in mice. Proc Natl Acad Sci USA. 2001;98:2005-10.

4. Waki H, Yamauchi T, Kamon J, Kita S, Ito Y, Hada Y, et al. Generation of globular fragment of adiponectin by leukocyte elastase secreted by monocytic cell line THP-1. Endocrinology. 2005;146:790-6.

5. Waki H, Yamauchi T, Kamon J, Ito Y, Uchida S, Kita S, et al. Impaired multimerization of human adiponectin mutants associated with diabetes molecular structure and multimer formation of adiponectin. J Biol Chem. 2003;278:40352-63.

6. Pajvani UB, Du X, Combs TP, Berg AH, Rajala MW, Schulthess T, et al. Structure-function studies of the adipocytesecreted hormone Acrp30/adiponectin implications for metabolic regulation and bioactivity. J Biol Chem. 2003;278: 9073-85.

7. Ebinuma H, Miida T, Yamauchi T, Hada Y, Hara K, Kubota N, et al. Improved ELISA for selective measurement of adiponectin 
multimers and identification of adiponectin in human cerebrospinal fluid. Clin Chem. 2007;53:1541-4.

8. Kusminski C, McTernan P, Schraw T, Kos K, O’hare J, Ahima $\mathrm{R}$, et al. Adiponectin complexes in human cerebrospinal fluid: distinct complex distribution from serum. Diabetologia. 2007; 50:634-42.

9. Kubota N, Yano W, Kubota T, Yamauchi T, Itoh S, Kumagai H, et al. Adiponectin stimulates AMP-activated protein kinase in the hypothalamus and increases food intake. Cell Metab. 2007; 6:55-68.

10. Neumeier M, Weigert J, Buettner R, Wanninger J, Schaffler A, Müller AM, et al. Detection of adiponectin in cerebrospinal fluid in humans. Am J Physiol Endocrinol Metab. 2007;293: E965-9.

11. Qi Y, Takahashi N, Hileman SM, Patel HR, Berg AH, Pajvani $\mathrm{UB}$, et al. Adiponectin acts in the brain to decrease body weight. Nat Med. 2004;10:524-9.

12. Yau SY, Li A, Hoo RL, Ching YP, Christie BR, Lee TM, et al. Physical exercise-induced hippocampal neurogenesis and antidepressant effects are mediated by the adipocyte hormone adiponectin. Proc Natl Acad Sci USA. 2014;111:15810-5.

13. Trujillo M, Scherer PE. Adiponectin-journey from an adipocyte secretory protein to biomarker of the metabolic syndrome. J Intern Med. 2005;257:167-75.

14. Kadowaki T, Yamauchi T. Adiponectin and adiponectin receptors. Endocr Rev. 2005;26:439-51.

15. Kahl KG, Schweiger U, Correll C, Muller C, Busch ML, Bauer $\mathrm{M}$, et al. Depression, anxiety disorders, and metabolic syndrome in a population at risk for type 2 diabetes mellitus. Brain Behav. 2015;5:e00306.

16. Pouwer F. Should we screen for emotional distress in type 2 diabetes mellitus? Nat Rev Endocrinol. 2009;5:665-71.

17. Leo R, Di Lorenzo G, Tesauro M, Cola C, Fortuna E, Zanasi M, et al. Decreased plasma adiponectin concentration in major depression. Neurosci Lett. 2006;407:211-3.

18. Narita K, Murata T, Takahashi T, Kosaka H, Omata N, Wada Y. Plasma levels of adiponectin and tumor necrosis factor-alpha in patients with remitted major depression receiving long-term maintenance antidepressant therapy. Prog Neuropsychopharmacol Biol Psychiatry. 2006;30:1159-62.

19. Lehto S, Huotari A, Niskanen L, Tolmunen T, Koivumaa-Honkanen H, Honkalampi K, et al. Serum adiponectin and resistin levels in major depressive disorder. Acta Psychiatr Scand. 2010; 121:209-15.

20. Zeugmann S, Quante A, Heuser I, Schwarzer R, Anghelescu I. Inflammatory biomarkers in 70 depressed inpatients with and without the metabolic syndrome. J Clin Psychiatry. 2010;71: 1007-16.

21. Liu J, Guo M, Zhang D, Cheng S-Y, Liu M, Ding J, et al. Adiponectin is critical in determining susceptibility to depressive behaviors and has antidepressant-like activity. Proc Natl Acad Sci USA. 2012;109:12248-53.

22. Yamauchi T, Kamon J, Ito Y, Tsuchida A, Yokomizo T, Kita S, et al. Cloning of adiponectin receptors that mediate antidiabetic metabolic effects. Nature. 2003;423:762-9.

23. Zhang D, Wang X, Wang B, Garza J, Fang X, Wang J, et al. Adiponectin regulates contextual fear extinction and intrinsic excitability of dentate gyrus granule neurons through AdipoR2 receptors. Mol Psychiatry. 2017;22:1044-55.

24. Sun F, Lei Y, You J, Li C, Sun L, Garza J, et al. Adiponectin modulates ventral tegmental area dopamine neuron activity and anxiety-related behavior through AdipoR1. Mol Psychiatry. 2018;24:126-44.

25. Yohn CN, Gergues MM, Samuels BA. The role of 5-HT receptors in depression. Mol Brain. 2017;10:28.
26. Albert PR, Benkelfat C, Descarries L. The neurobiology of depression-revisiting the serotonin hypothesis. I. Cellular and molecular mechanisms. Philos Trans R Soc Lond B Biol Sci. 2012;367:2378-81.

27. Morilak DA, Frazer A. Antidepressants and brain monoaminergic systems: a dimensional approach to understanding their behavioural effects in depression and anxiety disorders. Int $\mathbf{J}$ Neuropsychopharmacol. 2004;7:193-218.

28. Asberg M, Martensson B. Serotonin selective antidepressant drugs: past, present, future. Clin Neuropharmacol. 1993;16(Suppl 3): S32-44.

29. Wong DT, Horng JS, Bymaster FP, Hauser KL, Molloy BB. A selective inhibitor of serotonin uptake: Lilly 110140, 3-(p-trifluoromethylphenoxy)-N-methyl-3-phenylpropylamine. Life Sci. 1974;15:471-9.

30. Jacobsen JP, Medvedev IO, Caron MG. The 5-HT deficiency theory of depression: perspectives from a naturalistic 5-HT deficiency model, the tryptophan hydroxylase 2Arg439His knockin mouse. Philos Trans R Soc Lond B Biol Sci. 2012;367: 2444-59.

31. Delgado PL, Charney DS, Price LH, Aghajanian GK, Landis H, Heninger GR. Serotonin function and the mechanism of antidepressant action: reversal of antidepressant-induced remission by rapid depletion of plasma tryptophan. Arch Gen Psychiatry. 1990;47:411-8.

32. Delgado PL, Miller HL, Salomon RM, Licinio J, Krystal JH, Moreno FA, et al. Tryptophan-depletion challenge in depressed patients treated with desipramine or fluoxetine: implications for the role of serotonin in the mechanism of antidepressant action. Biol Psychiatry. 1999;46:212-20.

33. Akiskal HS, McKinney WT Jr. Depressive disorders: toward a unified hypothesis. Science. 1973;182:20-9.

34. Brown GL, Linnoila MI. CSF serotonin metabolite (5-HIAA) studies in depression, impulsivity, and violence. J Clin Psychiatry. 1990;51:31-41.

35. Caspi A, Sugden K, Moffitt TE, Taylor A, Craig IW, Harrington $\mathrm{H}$, et al. Influence of life stress on depression: moderation by a polymorphism in the 5-HTT gene. Science. 2003;301:386-9.

36. Zhang X, Gainetdinov RR, Beaulieu JM, Sotnikova TD, Burch LH, Williams RB, et al. Loss-of-function mutation in tryptophan hydroxylase-2 identified in unipolar major depression. Neuron. 2005;45:11-6.

37. Zill P, Baghai TC, Zwanzger P, Schule C, Eser D, Rupprecht R, et al. SNP and haplotype analysis of a novel tryptophan hydroxylase isoform (TPH2) gene provide evidence for association with major depression. Mol Psychiatry. 2004;9:1030-6.

38. Franklin KB, Paxinos G. The mouse brain in stereotaxic coordinates. 3. New York: Academic press; 2008.

39. Lei Y, Wang J, Wang D, Li C, Liu B, Fang X et al. SIRT1 in forebrain excitatory neurons produces sexually dimorphic effects on depression-related behaviors and modulates neuronal excitability and synaptic transmission in the medial prefrontal cortex. Mol Psychiatry. 2019. https://doi.org/10.1038/s41380-4101940352-41381.

40. Guo M, Li C, Lei Y, Xu S, Zhao D, Lu X-Y. Role of the adipose PPAR $\gamma$-adiponectin axis in susceptibility to stress and depression/ anxiety-related behaviors. Mol Psychiatry. 2017;22:1056-68.

41. Livak KJ, Schmittgen TD. Analysis of relative gene expression data using real-time quantitative PCR and the $2-\Delta \Delta C T$ method. Methods. 2001;25:402-8.

42. Malkesman O, Scattoni ML, Paredes D, Tragon T, Pearson B, Shaltiel G, et al. The female urine sniffing test: a novel approach for assessing reward-seeking behavior in rodents. Biol Psychiatry. 2010;67:864-71. 
43. Carrier N, Wang X, Sun L, Lu X-Y. Sex-specific and estrous cycle-dependent antidepressant-like effects and hippocampal Akt signaling of leptin. Endocrinology. 2015;156:3695-705.

44. Rodgers RJ, Dalvi A. Anxiety, defence and the elevated plusmaze. Neurosci Biobehav Rev. 1997;21:801-10.

45. Scott MM, Wylie CJ, Lerch JK, Murphy R, Lobur K, Herlitze S, et al. A genetic approach to access serotonin neurons for in vivo and in vitro studies. Proc Natl Acad Sci USA. 2005;102:16472-7.

46. Hendricks T, Francis N, Fyodorov D, Deneris ESJJoN. The ETS domain factor Pet-1 is an early and precise marker of central serotonin neurons and interacts with a conserved element in serotonergic genes. J Neurosci. 1999;19:10348-56.

47. Arita Y, Kihara S, Ouchi N, Takahashi M, Maeda K, Miyagawa $\mathrm{J}-\mathrm{i}$, et al. Paradoxical decrease of an adipose-specific protein, adiponectin, in obesity. Biochem Biophys Res Commun. 1999; 257:79-83.

48. Hotta K, Funahashi T, Arita Y, Takahashi M, Matsuda M, Okamoto $\mathrm{Y}$, et al. Plasma concentrations of a novel, adipose-specific protein, adiponectin, in type 2 diabetic patients. Arterioscler Thromb Vasc Biol. 2000;20:1595-9.

49. Combs TP, Berg AH, Rajala MW, Klebanov S, Iyengar P, Jimenez-Chillaron JC, et al. Sexual differentiation, pregnancy, calorie restriction, and aging affect the adipocyte-specific secretory protein adiponectin. Diabetes. 2003;52:268-76.

50. Liu Z, Zhou J, Li Y, Hu F, Lu Y, Ma M, et al. Dorsal raphe neurons signal reward through 5-HT and glutamate. Neuron. 2014;81:1360-74.

51. Li Y, Zhong W, Wang D, Feng Q, Liu Z, Zhou J, et al. Serotonin neurons in the dorsal raphe nucleus encode reward signals. Nat Commun. 2016;7:10503.

52. Willner P. Validity, reliability and utility of the chronic mild stress model of depression: a 10-year review and evaluation. Psychopharmacology. 1997;134:319-29.

53. Garza JC, Guo M, Zhang W, Lu X-Y. Leptin restores adult hippocampal neurogenesis in a chronic unpredictable stress model of depression and reverses glucocorticoid-induced inhibition of GSK-3 $\beta / \beta$-catenin signaling. Mol Psychiatry. 2012;17:790-808.

54. Teissier A, Chemiakine A, Inbar B, Bagchi S, Ray RS, Palmiter $\mathrm{RD}$, et al. Activity of raphe serotonergic neurons controls emotional behaviors. Cell Rep. 2015;13:1965-76.

55. Ohmura Y, Tanaka KF, Tsunematsu T, Yamanaka A, Yoshioka M. Optogenetic activation of serotonergic neurons enhances anxiety-like behaviour in mice. Int $\mathrm{J}$ Neuropsychopharmacol. 2014;17:1777-83.

56. Nishitani N, Nagayasu K, Asaoka N, Yamashiro M, Andoh C, Nagai Y, et al. Manipulation of dorsal raphe serotonergic neurons modulates active coping to inescapable stress and anxietyrelated behaviors in mice and rats. Neuropsychopharmacology. 2019;44:721-32.

57. Guo M, Lu Y, Garza JC, Li Y, Chua SC, Zhang W, et al. Forebrain glutamatergic neurons mediate leptin action on depression-like behaviors and synaptic depression. Transl Psychiatry. 2012;2:e83.

58. Walther DJ, Peter JU, Bashammakh S, Hortnagl H, Voits M, Fink $\mathrm{H}$, et al. Synthesis of serotonin by a second tryptophan hydroxylase isoform. Science. 2003;299:76.

59. Fitzpatrick PF. Tetrahydropterin-dependent amino acid hydroxylases. Annu Rev Biochem. 1999;68:355-81.

60. Blakely RD, Berson HE, Fremeau RT Jr., Caron MG, Peek MM, Prince HK, et al. Cloning and expression of a functional serotonin transporter from rat brain. Nature. 1991;354:66-70.

61. Wong DT, Bymaster FP, Engleman EA. Prozac (fluoxetine, Lilly 110140), the first selective serotonin uptake inhibitor and an antidepressant drug: twenty years since its first publication. Life Sci. 1995;57:411-41.
62. Richardson LP, Davis R, Poulton R, McCauley E, Moffitt TE, Caspi A, et al. A longitudinal evaluation of adolescent depression and adult obesity. Arch Pediatr Adolesc Med. 2003;157:739-45.

63. Bornstein S, Schuppenies A, Wong M, Licinio J. Approaching the shared biology of obesity and depression: the stress axis as the locus of gene-environment interactions. Mol Psychiatry. 2006;11:892-902.

64. Lee S, Paz-Filho G, Mastronardi C, Licinio J, Wong ML. Is increased antidepressant exposure a contributory factor to the obesity pandemic? Transl Psychiatry. 2016;6:e759.

65. Rosmond R, Lapidus L, Björntorp P. The influence of occupational and social factors on obesity and body fat distribution in middle-aged men. Int J Obes Relat Metab Disord. 1996;20: 599-607.

66. Golden SH, Lazo M, Carnethon M, Bertoni AG, Schreiner PJ, Diez Roux AV, et al. Examining a bidirectional association between depressive symptoms and diabetes. JAMA. 2008;299: 2751-9.

67. Yamauchi T, Kamon J, Waki H, Terauchi Y, Kubota N, Hara K, et al. The fat-derived hormone adiponectin reverses insulin resistance associated with both lipoatrophy and obesity. Nat Med. 2001;7:941-6.

68. Cnop M, Havel PJ, Utzschneider K, Carr D, Sinha M, Boyko E, et al. Relationship of adiponectin to body fat distribution, insulin sensitivity and plasma lipoproteins: evidence for independent roles of age and sex. Diabetologia. 2003;46:459-69.

69. Craven SE, Lim K-C, Ye W, Engel JD, de Sauvage F, Rosenthal AJD. Gata2 specifies serotonergic neurons downstream of sonic hedgehog. Development. 2004;131:1165-73.

70. Hendricks TJ, Fyodorov DV, Wegman LJ, Lelutiu NB, Pehek EA, Yamamoto B, et al. Pet-1 ETS gene plays a critical role in 5-HT neuron development and is required for normal anxiety-like and aggressive behavior. Neuron. 2003;37:233-47.

71. Zhuang X, Masson J, Gingrich JA, Rayport S, Hen R. Targeted gene expression in dopamine and serotonin neurons of the mouse brain. J Neurosci Methods. 2005;143:27-32.

72. Bachmanov AA, Tordoff MG, Beauchamp GKJCs. Sweetener preference of C57BL/6ByJ and 129P3/J mice. Chem Senses. 2001;26:905-13.

73. Côté F, Thévenot E, Fligny C, Fromes Y, Darmon M, Ripoche MA, et al. Disruption of the nonneuronal tph 1 gene demonstrates the importance of peripheral serotonin in cardiac function. Proc Natl Acad Sci USA. 2003;100:13525-30.

74. Patel PD, Pontrello C, Burke S. Robust and tissue-specific expression of TPH2 versus TPH1 in rat raphe and pineal gland. Biol Psychiatry. 2004;55:428-33.

75. Booij L, Van der Does AJ, Riedel WJ. Monoamine depletion in psychiatric and healthy populations: review. Mol Psychiatry. 2003;8:951-73.

76. Mann JJ, Malone KM. Cerebrospinal fluid amines and higherlethality suicide attempts in depressed inpatients. Biol Psychiatry. 1997:41:162-71.

77. Jacobsen JP, Siesser WB, Sachs BD, Peterson S, Cools MJ, Setola $\mathrm{V}$, et al. Deficient serotonin neurotransmission and depression-like serotonin biomarker alterations in tryptophan hydroxylase 2 (Tph2) loss-of-function mice. Mol Psychiatry. 2012;17:694-704.

78. Zill P, Buttner A, Eisenmenger W, Moller HJ, Bondy B, Ackenheil M. Single nucleotide polymorphism and haplotype analysis of a novel tryptophan hydroxylase isoform (TPH2) gene in suicide victims. Biol Psychiatry. 2004;56:581-6.

79. Yoon HK, Kim YK. TPH2 -703G/T SNP may have important effect on susceptibility to suicidal behavior in major depression. Prog Neuropsychopharmacol Biol Psychiatry. 2009;33:403-9.

80. Haghighi F, Bach-Mizrachi H, Huang YY, Arango V, Shi S, Dwork AJ, et al. Genetic architecture of the human 
tryptophan hydroxylase 2 gene: existence of neural isoforms and relevance for major depression. Mol Psychiatry. 2008;13: 813-20.

81. Nishizawa S, Benkelfat C, Young S, Leyton M, Mzengeza S, De Montigny C, et al. Differences between males and females in rates of serotonin synthesis in human brain. Proc Natl Acad Sci USA. 1997;94:5308-13.

82. Mefford IN, Rudorfer MV, Linnoila M, Potter WZ. Interacting neurotransmitter systems. A non-experimental approach to the 5HIAA-HVA correlation in human CSF. J Psychiatr Res. 1986; 20:175-93.
83. Young SN, Gauthier S, Anderson GM, Purdy WC. Tryptophan, 5-hydroxyindoleacetic acid and indoleacetic acid in human cerebrospinal fluid: interrelationships and the influence of age, sex, epilepsy and anticonvulsant drugs. J Neurol Neurosurg Psychiatry. 1980;43:438-45.

84. Zhou J, Jia C, Feng Q, Bao J, Luo M. Prospective coding of dorsal raphe reward signals by the orbitofrontal cortex. J Neurosci. 2015; 35:2717-30.

85. Zhong W, Li Y, Feng Q, Luo M. Learning and stress shape the reward response patterns of serotonin neurons. J Neurosci. 2017; $37: 8863-75$. 